MÁRCIA KAZUMI NAGAMINE

\title{
EFEITOS DOS EXTRATOS ETANÓLICO, BUTANÓLICO OU AQUOSO DE Pfaffia paniculata SOBRE A PROLIFERAÇÃO DE LINHAGENS TUMORAIS DE CÉLULAS MAMÁRIAS HUMANAS
}




\section{EFEITOS DOS EXTRATOS ETANÓLICO, BUTANÓLICO OU AQUOSO DE Pfaffia paniculata SOBRE A PROLIFERAÇÃO DE LINHAGENS TUMORAIS DE CÉLULAS MAMÁRIAS HUMANAS}

Dissertação apresentada ao Programa de Pósgraduação em Patologia Experimental e Comparada da Faculdade de Medicina Veterinária e Zootecnia da Universidade de São Paulo, para a obtenção do título de Mestre em Ciências

Departamento:

Patologia

Área de concentração:

Patologia Experimental e Comparada

Orientador:

Prof $^{a}$. Dr ${ }^{a}$. Maria Lúcia Zaidan Dagli 
Autorizo a reprodução parcial ou total desta obra, para fins acadêmicos, desde que citada a fonte.

DADOS INTERNACIONAIS DE CATALOGAÇÃO-NA-PUBLICAÇÃO

(Biblioteca da Faculdade de Medicina Veterinária e Zootecnia da Universidade de São Paulo)

T.1549 Nagamine, Márcia Kazumi

FMVZ Efeitos dos extratos estanólico, butanólico ou aquoso de Pfaffia paniculata sobre a proliferação de linhagens tumorais de células mamárias humanas / Márcia Kazumi Nagamine. - São Paulo : M. K. Nagamine, 2005.

75 f. : il.

Dissertação (mestrado) - Universidade de São Paulo. Faculdade de Medicina Veterinária e Zootecnia. Departamento de Patologia, 2005.

Programa de Pós-graduação: Patologia Experimental e Comparada.

Área de concentração: Patologia Experimental e Comparada.

Orientador: Profa. Dra. Maria Lucia Zaidan Dagli.

1. Neoplasias. 2. Cultura de células. 3. Plantas medicinais. I. Título. 


\section{UNIVERSIDADE DE SÃO PAULO \\ Faculdade de Medicina Veterinaria e Zootecnia \\ Assistência Acadêmica}

\section{PARECER}

Interessado: Márcia Kazumi Nagamine

Assunto: Protocolo de experimentação adotado em experimento animal.

A Comissão de Bioética da Faculdade de Medicina Veterinária e Zootecnia da Universidade de São Paulo, após analisar o projeto sob o número 701/2005, intitulado: “Efeitos da Pfaffia paniculata sobre a proliferação celular e a capacidade de comunicação intercelular por junções comunicantes do tipo "gap" em linhagens tumorais de células mamárias humanas", utilizando cultivos celulares, sob responsabilidade da Profa. Dra. Maria Lúcia Zaidan Dagli, constatou que o mesmo foi realizado de acordo com os princípios de bioética, adotados por esta Comissão.

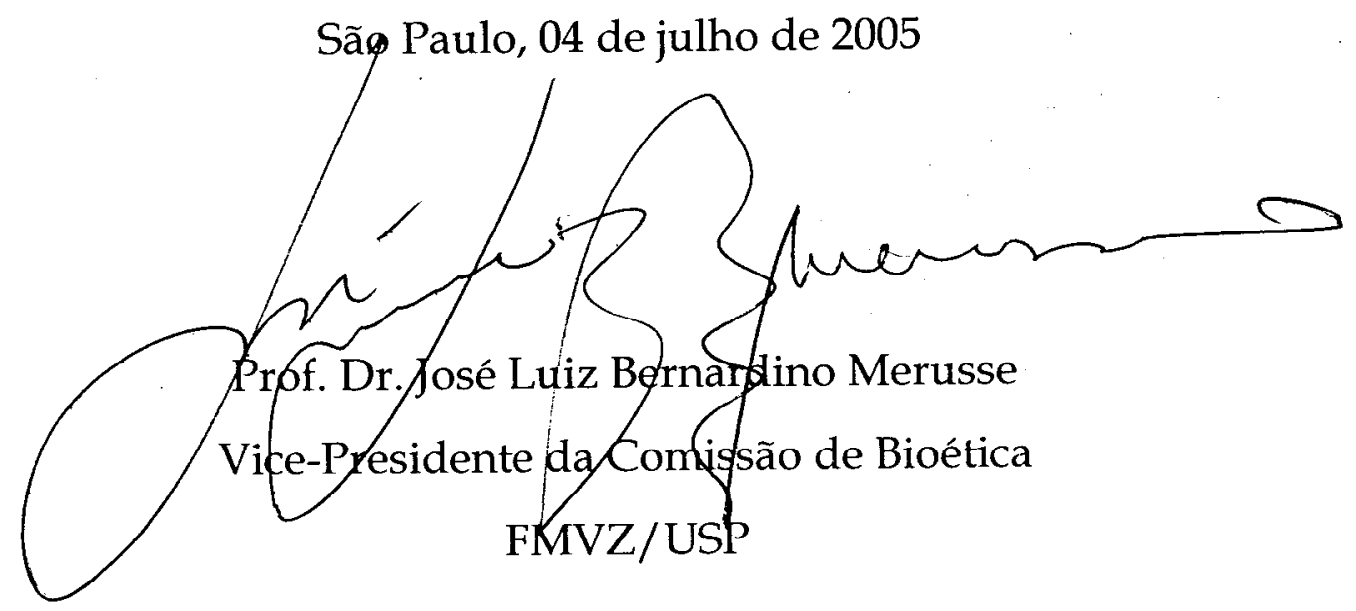




\section{FOLHA DE AVALIAÇÃO}

Nome do autor: NAGAMINE, Márcia Kazumi

Título: Efeitos dos extratos etanólico, butanólico ou aquoso de Pfaffia paniculata sobre a proliferação de linhagens tumorais de células mamárias humanas

Dissertação apresentada ao Programa de Pósgraduação em Patologia Experimental e Comparada da Faculdade de Medicina Veterinária e Zootecnia da Universidade de São Paulo, para a obtenção do título de Mestre em Ciências

Data:

Banca Examinadora

Prof. Dr.

Instituição

Assinatura

Julgamento

Prof. Dr.

Instituição

Assinatura

Julgamento

Prof. Dr.

Instituição

Assinatura

Julgamento 
À Malú, um anjo que caiu do céu,

minha orientadora do coração, a quem tenho um grande carinho e admiração,

por tornar possível um desejo de infância. 
À minha tia Haruko,

sem a qual não teria sido possível a realização deste trabalho. 
À minha família, que tanto amo 


\section{AGRADECIMENTOS}

À FAPESP, pelo apoio financeiro concedido, sem o qual não seria possível a realização deste estudo.

Ao Prof. Dr. José Alexandre Marzagão Barbuto, por ceder o laboratório para a realização deste trabalho, pela oportunidade de ampliar meus conhecimentos, por todo aprendizado, por tudo (estatisticamente significante, $\mathrm{P}<0,0001$ ).

À Célia Maria, do Laboratório de Imunologia de Tumores do Instituto de Ciências Biomédicas IV-USP, por me ensinar os princípios da cultura de células, pela força, e pela amizade.

À Camila Raposo, pela paciência e vontade em ensinar as técnicas utilizadas em cultura celular.

À Patrícia Matsuzaki, a iniciadora dos trabalhos com a Pfaffia neste laboratório, pela força e amizade.

Ao Prof. Dr. Idércio L. Sinhorini do Departamento de Patologia da FMVZ-USP, pela atenção dispensada no auxílio com a microscopia eletrônica.

À Shirlei, pelo processamento do material para microscopia eletrônica, pela força e otimismo.

À Prof ${ }^{a}$. Dra . Élia Caldini e Hélio, da Faculdade de Medicina-USP, pelo auxílio prestado com o material de microscopia eletrônica.

Ao Gerson, do Instituto de Ciências Biomédicas I, pela ajuda na captura das imagens da microscopia eletrônica.

Ao Prof. Dr. João P. Neto, do Departamento de Patologia da FMVZ-USP, pelo apoio na realização deste projeto.

Ao Prof. Dr. Roger Chammas, da Faculdade de Medicina-USP, pela atenção e disponibilidade, pelas disciplinas, e por ser uma pessoa encantadora. 
À Prof ${ }^{a}$. Dr ${ }^{\mathrm{a}}$. Mitsue Haraguchi, do Instituto Biológico, pela obtenção dos extratos da raiz e pela troca de conhecimentos.

Ao Prof. Dr. Gokithi Akisue, pelo fornecimento da raiz utilizada neste projeto.

Ao Prof. Dr. Francisco Blazquez, do Departamento de Anatomia da FMVZ-USP, pela ajuda na realização deste trabalho.

À Prof ${ }^{a}$. Dra . Simone e ao Prof. Dr. Nilson, Sandra e Priscila, do Departamento de Medicina Preventiva e Saúde Animal da FMVZ-USP, pela avaliação microbiológica dos extratos.

Ao Prof. Dr. Jorge Timenetsky, Maurício e Lucas, do Laboratório de Micoplasma do Institiuto de Ciências Biomédicas II, pela análise das culturas de células.

Ao Prof. Dr. Alejandro Katzin, do Instituto de Ciências Biomédicas II, por ajudar na liofilização dos extratos.

Ao Zé Luis, Silvinha, Cyntia e Ivone, pela ajuda na realização dos experimentos.

À Nica, Pati, Sil, Tereza, Zezinho, Heidge, Kátia, Lucas e Tarso, pela amizade, altruísmo e convivência.

A todos do Laboratório de Imunologia de Tumores do Instituto de Ciências Biomédicas IV, e do Laboratório de Oncologia Experimental da FMVZ-USP, pela convivência e troca, e pelos momentos mais desafiadores e emocionantes da minha história na faculdade (foi um grande aprendizado !).

À Sílvia Inglese Ribes, pelo apoio e compreensão nos momentos mais difíceis da minha vida.

À Ana Carolina Caldas Alves, a quem devo eterna gratidão, por me ajudar a enxergar que a vida pode ser mais leve, e que cada um é responsável por sua própria felicidade. Este pode ser considerado o reflexo de seu trabalho.

A Deus, aos anjos e espíritos bons que iluminam minha vida. 


\section{RESUMO}

NAGAMINE, M. K. Efeitos dos extratos etanólico, butanólico ou aquoso de Pfaffia paniculata sobre a proliferação de linhagens tumorais de células mamárias humanas. [Effects of ethanolic, butanolic or aqueous extracts of Pfaffia paniculata on human breast tumor cell lines proliferation]. 2005. 75 f. Dissertação (Mestrado em Ciências) - Faculdade de Medicina Veterinária e Zootecnia, Universidade de São Paulo, São Paulo, 2005.

As raízes de Pfaffia paniculata (Ginseng brasileiro) são comercialmente encontradas como cápsulas contendo as raízes pulverizadas, misturadas ou não ao extrato etanólico destas raízes. Estas raízes são popularmente recomendadas para vários propósitos, e têm sido utilizadas na terapia contra o câncer pela medicina popular. Os principais componentes encontrados nestas raízes já isolados incluem o ácido pfáffico e os pfaffosideos $A, C, D, E$ e $F$; estes componentes inibiram o crescimento de células do melanoma B-16, demonstrado em um outro estudo. O objetivo deste estudo foi investigar os efeitos dos extratos etanólico, butanólico ou aquoso das raízes de Pfaffia paniculata sobre o crescimento das linhagens tumorais de células mamárias humanas MCF-7 e SKBR-3, utilizando método colorimétrico (cristal violeta) e quantificação das células que incorporaram bromodeoxiuridina (BrdU). A coloração por laranja de acridina/brometo de etídeo foi utilizada para avaliar morte celular, e as alterações subcelulares foram avaliadas por microscopia eletrônica. O extrato butanolico apresentou efeitos citotóxicos nas linhagens MCF-7 e SKBR-3. Morte celular foi observada pelo tratamento com o extrato butanólico por $1 \mathrm{~h}$; alterações morfológicas foram observadas com $500 \mu \mathrm{g} / \mathrm{mL}$ deste extrato, após $24 \mathrm{~h}$ de tratamento. Após o tratamento por $48 \mathrm{~h}$ com o extrato butanólico nesta mesma concentração, foi observado degeneração de componentes citoplasmáticos e 
alterações morfológicas sugestivas de morte celular. O tratamento com $1000 \mu \mathrm{g} / \mathrm{mL}$ deste extrato levou a profundas alterações citoplasmáticas e nucleares, incompatíveis com a viabilidade celular. O tratamento com o extrato etanólico não causou efeitos significantes no crescimento das células MCF-7 e SKBR-3; o extrato aquoso, por outro lado, estimulou o crescimento das células MCF-7, após o tratamento por $1 \mathrm{~h}$. Estes resultados indicam efeitos citotóxicos exercidos pelo extrato butanólico das raízes de Pfaffia paniculata em linhagens celulares de tumor de mama humano.

Palavras-chave: Neoplasias. Cultura de células. Plantas medicinais. 


\begin{abstract}
NAGAMINE, M. K. Effects of ethanolic, butanolic or aqueous extracts of Pfaffia paniculata on human breast tumor cell lines proliferation. [Efeitos dos extratos etanólico, butanólico ou aquoso de Pfaffia paniculata sobre a proliferação de linhagens tumorais de células mamárias humanas]. 2005. 75 f. Dissertação (Mestrado em Ciências) - Faculdade de Medicina Veterinária e Zootecnia, Universidade de São Paulo, São Paulo, 2005.
\end{abstract}

The roots of Pfaffia paniculata (Brazilian ginseng) are commercially available as capsules containing the powdered roots, mixed or not with the ethanolic extract of the roots. These roots have been populary recommended for many purposes, and have also been used on cancer therapy by folk medicine. The main components found in these roots that have already been isolated include pfaffic acid and pfaffosides $A, C$, $D, E$ and $F$; these components inhibited the growth of melanoma B-16 cells, as shown in another study. The aim of this study was to investigate the effects of ethanolic, butanolic or aqueous extract of the roots of Pfaffia paniculata on the growth of human breast tumor cell lines MCF-7 and SKBR-3, using a colorimetric method (crystal violet) and quantification of bromodeoxiuridine (BrdU) positive cells. Acridine orange/ethidium bromide staining was utilized to evaluate cell death, and subcellular alteration was evaluated by electron microscopy. The butanolic extract presented cytotoxic effects in MCF-7 and SKBR-3 cell lines. Cell death was observed following treatment with the butanolic extract for $1 \mathrm{~h}$; morphologic alterations were observed with $500 \mu \mathrm{g} / \mathrm{mL}$ of this extract, after 24 and $48 \mathrm{~h}$ of treatment. Following treatment for $48 \mathrm{~h}$ with the butanolic extract with this same concentration, degeneration of cytoplasmic components and morphological alterations suggestive of cell death were observed. Treatment with $1000 \mu \mathrm{g} / \mathrm{mL}$ of this extract lead to profound cytoplasmic and 
nuclear alterations, incompatible with cell viability. The treatment with ethanolic extract didn't lead to significant effects on the growth of MCF-7 and SKBR-3 cells; the aqueous extract, on the other hand, stimulated the growth of MCF-7 cells, following treatment for 1 hour. These results point to cytotoxic effects exerted by the butanolic extract from the roots of Pfaffia paniculata on human breast tumor cell lines.

Key words: Neoplasia. Cell culture. Medicinal plants. 
1 INTRODUÇÃO

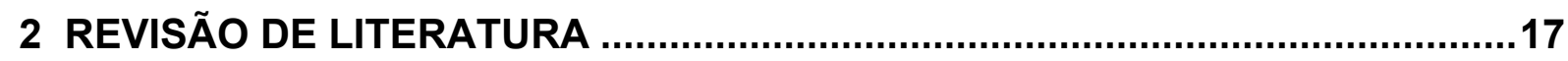

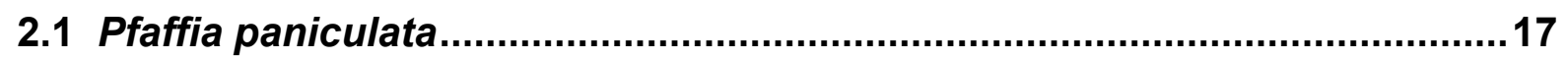

2.2 Compostos presentes na P.paniculata e ações farmacológicas .................22

2.3 Câncer e busca de novos agentes ..............................................................24

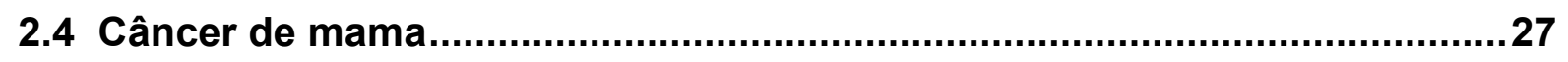

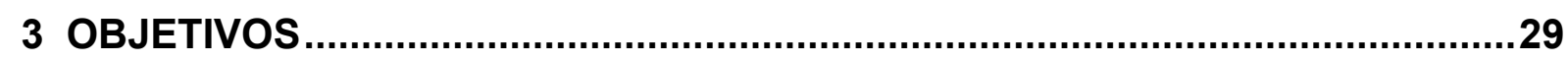

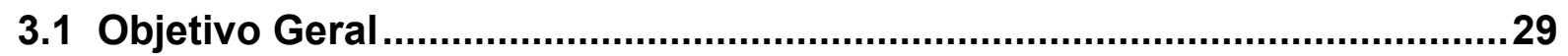

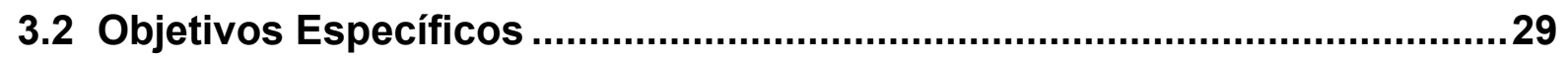

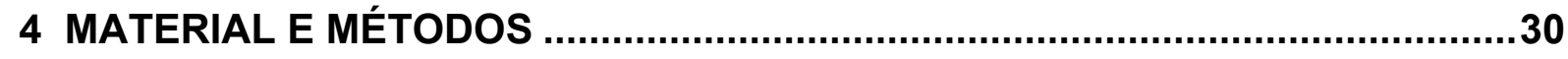

4.1 Linhagem de células tumorais mamárias humanas MCF-7 e SKBR-3........30

4.2 Raízes de Pfaffia paniculata ...................................................................... 30

4.3 Obtenção do extrato e resíduos de Pfaffia paniculata ..................................31

4.4 Manutenção e tratamento da cultura de células..........................................32

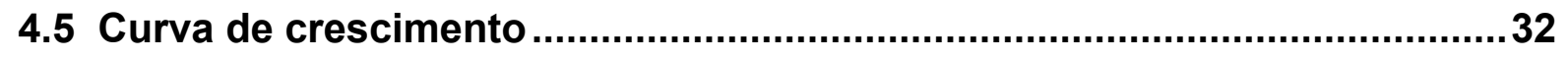

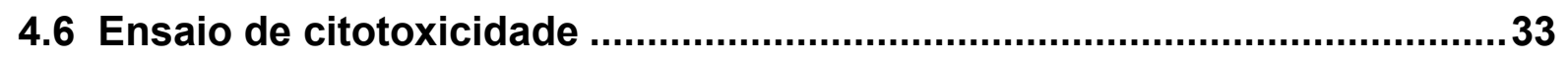

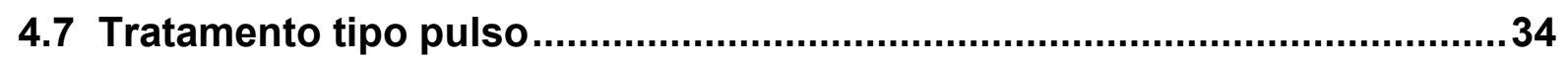

4.8 Deteç̧ão de morte celular utilizando laranja de acridina e brometo de etídio

4.9 Quantificação da fração proliferativa por meio da marcação de núcleos

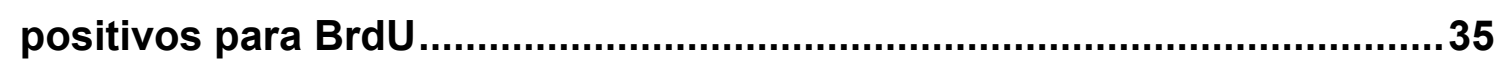

4.10 Verificação de alterações subcelulares (microscopia eletrônica de transmissão) 


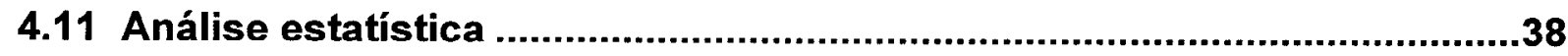

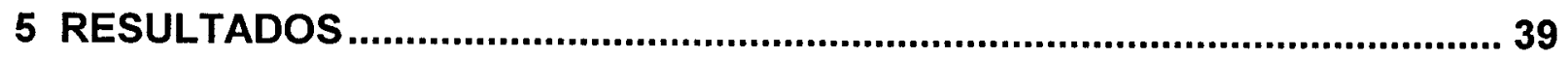

5.1 Rendimento dos extratos..................................................................39

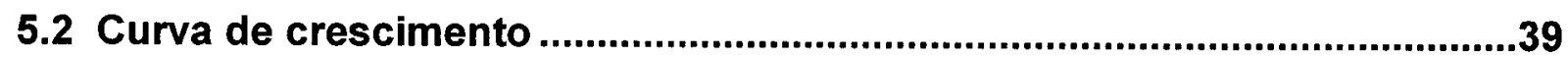

5.3 Ensaio de citotoxicidade......................................................................41

5.4 Deteç̧ão de morte celular pelo método da laranja de acridina e brometo de etídio 50

5.6 Verificação de células em proliferação por meio da marcação de núcleos que incorporam bromodeoxiuridina (BrdU) ........................................57

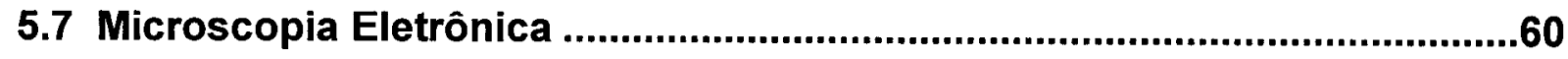

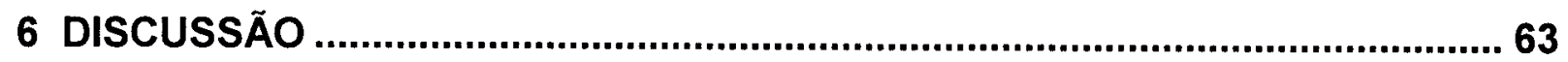

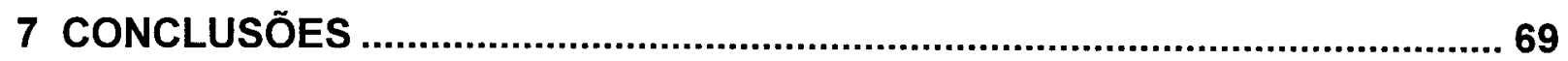

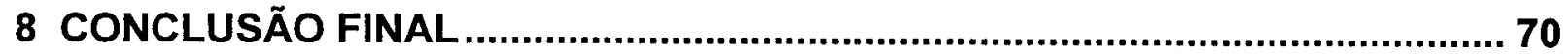

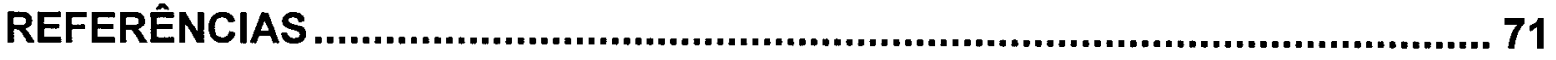




\section{INTRODUÇÃO}

O consumo da raiz de Pfaffia paniculata como remédio pela população faz parte do conhecimento popular adquirido dos povos indígenas para o tratamento de várias afecções. A P.paniculata também é utilizada como tônico e adaptógeno, sendo comercializada livremente em farmácias em forma de cápsulas contendo a raiz da P.paniculata em associações com outros compostos ou pura.

Existem poucos estudos a respeito dos efeitos farmacológicos da P.paniculata, não possuindo a maioria deles comprovação científica. O comércio indiscriminado e a falta de conhecimento científico a respeito desta planta são fatores preocupantes. A P.paniculata tem indicações para uma série de doenças, inclusive o câncer.

O fato desta planta possuir compostos que apresentaram efeitos inibitórios sobre o crescimento do melanoma B-16 em cultura e efeitos antitumorais em alguns modelos in vivo, nos leva a indagar se a Pfaffia paniculata poderia suprimir o crescimento de células tumorais mamárias humanas in vitro.

Neste trabalho foram avaliados os efeitos dos extratos etanólico, butanólico e aquoso sobre o crescimento de células mamárias humanas MCF-7 e SKBR-3 utilizando o método do cristal violeta, detecção de morte celular por laranja de acridina e brometo de etídio, avaliação da proliferação celular pela imunomarcação de núcleos que incorporaram a BrdU e alterações ultraestruturais por microscopia eletrônica. 


\section{REVISÃO DE LITERATURA}

\subsection{Pfaffia paniculata}

A Pfaffia paniculata (Martius) Kuntze é conhecida popularmente como ginseng brasileiro e paratudo, referindo-se a seu uso similar aos dos ginsengs importados para tratar uma ampla variedade de doenças e para melhorar a capacidade mental e energética.

Esta planta é nativa do Brasil, e também é encontrada em outras regiões tropicais, que incluem a bacia Amazônica, Equador, Panamá, Paraguai, Peru e Venezuela (DWECK, 2005). Outros nomes pelo qual é conhecida são fáfia e corango-açu.

Sua utilização tem origem desde épocas remotas pelos povos indígenas, principalmente pelas suas propriedades adaptógenas, ou seja, como tônico prescrito após períodos de debilidade (ELKINS, 1997). Além disso, é utilizada atualmente para combater uma variedade de afecções circulatórias e neurológicas, distúrbio hormonal, fadiga crônica, diabetes, taxa elevada de colesterol, para fortalecer o sistema imunológico e como auxiliar no tratamento de câncer, e ainda como afrodisíaco (ELKINS, 1997; OLIVEIRA; AKISUE; AKISUE, 1980; PARADISE, 2005). O nome popular paratudo provém dessa utilização "para tudo". 

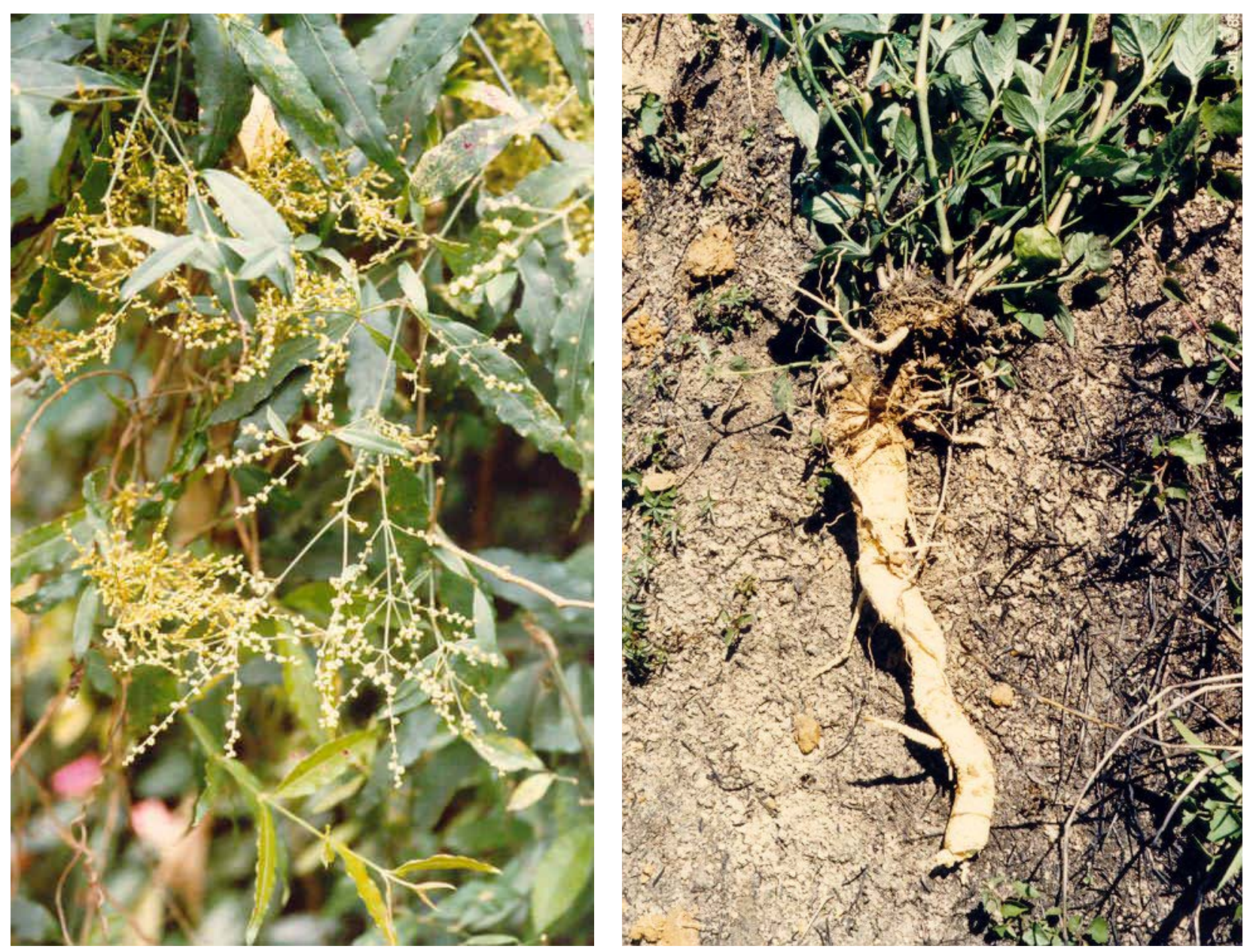

Figura 1 - Folhas e raízes de Pfaffia paniculata. Fotos cedidas pelo Prof. Dr. Gokithi Akissue.

A Pfaffia paniculata possui raízes em forma napiforme, assumindo o conjunto raiz principal e raízes secundárias aspectos bizarros, que muitas vezes lembram a forma humana. Devido a este fato, foi provavelmente atribuído o nome ginseng brasileiro (OLIVEIRA; AKISUE; AKISUE, 1980). Entretanto, o ginseng considerado verdadeiro pertence ao gênero Panax, da família Araliaceae, enquanto a P.paniculata pertence à família Amaranthaceae, não possuindo correlações botânicas. Portanto, a composição química é bem diferente entre os dois tipos de ginsengs, tendo como conseqüência ações farmacológicas distintas (OLIVEIRA; AKISUE; AKISUE, 1980). 
Para muitos, o ginseng verdadeiro é o ginseng asiático (Panax ginseng). Na Colúmbia Britânica (Canadá) foram definidos como ginsengs verdadeiros apenas três espécies de Panax que são comercializados: Panax ginseng (ginseng asiático), Panax quinquefolius (ginseng americano) e Panax notoginseng (notoginseng), sendo os demais ginsengs considerados impostores ou apenas relacionados à família Araliaceae (Tabelas 1 e 2). A preocupação em diferenciar os ginsengs verdadeiros e impostores está baseada principalmente na proteção ao público consumidor, pela diversidade de espécies e plantas de famílias diferentes que são denominadas pelo nome comum ginseng (BRITISH, 1999). 
Tabela 1 - Classificação de plantas consideradas ginsengs (Panax sp.) segundo o Ministério da Agricultura e Alimentos da Colúmbia Britânica - 1999

\begin{tabular}{|c|c|c|c|c|}
\hline classificação & nome botânico & nome popular & $\begin{array}{l}\text { região onde é } \\
\text { nativo }\end{array}$ & comentários \\
\hline \multirow[t]{3}{*}{$\begin{array}{c}\text { ginsengs } \\
\text { verdadeiros } \\
\text { (família Araliaceae) }\end{array}$} & Panax ginseng & $\begin{array}{l}\text { Asian ginseng } \\
\text { Chinese ginseng } \\
\text { Korean ginseng } \\
\text { Jen-shen ou hong } \\
\text { shen } \\
\text { Sheng shai shen }\end{array}$ & $\begin{array}{l}\text { Noroeste da China } \\
\text { Sudeste da Rússia }\end{array}$ & $\begin{array}{c}\text { Ginseng utilizado na } \\
\text { China por } 3.000 \text { a } 5.000 \\
\text { anos. Muitas vezes } \\
\text { chamado de verdadeiro } \\
\text { ginseng }\end{array}$ \\
\hline & $\begin{array}{c}\text { Panax } \\
\text { quinquefolius }\end{array}$ & $\begin{array}{l}\text { American ginseng } \\
\text { Canadian ginseng } \\
\text { North American } \\
\text { ginseng } \\
\text { Shang } \\
\text { Xi yang shen }\end{array}$ & $\begin{array}{l}\text { Leste da América } \\
\text { do Norte (sul de } \\
\text { Ontário e Quebec } \\
\text { até Geórgia) }\end{array}$ & $\begin{array}{l}\text { Utilizado pelos } \\
\text { indígenas norte- } \\
\text { americanos pelas } \\
\text { mesmas razões que os } \\
\text { chineses usavam } P . \\
\text { ginseng }\end{array}$ \\
\hline & Panax notoginseng & $\begin{array}{l}\text { Notoginseng } \\
\text { South China } \\
\text { ginseng } \\
\text { Ginseng sanchi } \\
\text { San-qi ou ginseng } \\
\text { san qui } \\
\text { Teinqi }\end{array}$ & $\begin{array}{c}\text { Sudoeste da China } \\
\text { e Vietnam }\end{array}$ & $\begin{array}{l}\text { Está ganhando } \\
\text { popularidade no mundo } \\
\text { da medicina natural. }\end{array}$ \\
\hline \multirow[t]{11}{*}{$\begin{array}{c}\text { Outros ginsengs } \\
\text { (família Araliaceae) }\end{array}$} & Panax japonicus & $\begin{array}{c}\text { Japanese ginseng } \\
\text { Bamboo ginseng } \\
\text { Zhuijieshen } \\
\text { Tikusetuninzin } \\
\text { Chu-chien-jen-shen }\end{array}$ & Japão até Índia & $\begin{array}{c}\text { Estas espécies são } \\
\text { pouco utilizadas }\end{array}$ \\
\hline & $\begin{array}{l}\text { Panax } \\
\text { pseudoginseng }\end{array}$ & $\begin{array}{l}\text { Tienchi ginseng } \\
\text { Chai-jen-shen }\end{array}$ & China ocidental & \\
\hline & $\begin{array}{l}\text { Panax } \\
\text { stipuleanatus }\end{array}$ & $\begin{array}{l}\text { Pingbiann ginseng } \\
\text { Ping-ping }\end{array}$ & $\begin{array}{l}\text { China ocidental e } \\
\text { Norte do Vietnam }\end{array}$ & \multirow{9}{*}{$\begin{array}{l}\text { Estas outras espécies } \\
\text { de Panax provavelmente } \\
\text { não são encontrados } \\
\text { comercialmente em } \\
\text { nenhum lugar. O Panax } \\
\text { trifolius não possui valor } \\
\text { medicinal }\end{array}$} \\
\hline & Panax trifolius & Dwarf ginseng & $\begin{array}{l}\text { Leste da América } \\
\text { do Norte }\end{array}$ & \\
\hline & $\begin{array}{l}\text { Panax } \\
\text { zingiberenseis }\end{array}$ & $\begin{array}{l}\text { San qi ginseng } \\
\text { Chaing-chuang }\end{array}$ & $\begin{array}{l}\text { China ocidental e } \\
\text { Norte do Vietnam }\end{array}$ & \\
\hline & & $\begin{array}{l}\text { Ginger shaped } \\
\text { ginseng }\end{array}$ & & \\
\hline & Panax sinensis & & & \\
\hline & Panax major & & & \\
\hline & Panax bipinnatifidus & & & \\
\hline & Panax omeiensis & & & \\
\hline & Panax wangianus & & & \\
\hline
\end{tabular}

Fonte: British Columbia Ministry of Agriculture and Food 
Tabela 2 - Classificação de plantas relacionadas ao ginseng verdadeiro (família Araliaceae) e plantas impostoras, segundo o Ministério da Agricultura e Alimentos da Colúmbia Britânica - 1999

\begin{tabular}{|c|c|c|c|c|}
\hline classificação & nome botânico & nome popular & região onde é nativo & comentários \\
\hline \multirow[t]{4}{*}{$\begin{array}{l}\text { Plantas relacionadas } \\
\text { (família Araliaceae) }\end{array}$} & $\begin{array}{l}\text { Eleutherococcus } \\
\text { senticosis }\end{array}$ & $\begin{array}{l}\text { Siberian ginseng } \\
\text { Eleuthro ginseng } \\
\text { Ciwujia }\end{array}$ & $\begin{array}{l}\text { Rússia oriental } \\
\text { Nordeste da China } \\
\text { Norte do Japão }\end{array}$ & $\begin{array}{l}\text { Tem propriedades similares } \\
\text { ao do grupo dos ginsengs, } \\
\text { mas não as mesmas }\end{array}$ \\
\hline & $\begin{array}{l}\text { Acanthopanax } \\
\text { sessifloris }\end{array}$ & $\begin{array}{l}\text { Wujiashen } \\
\text { Thorny wujia ginseng }\end{array}$ & China & $\begin{array}{c}\text { Não possui propriedades } \\
\text { similares ao grupo dos } \\
\text { ginsengs }\end{array}$ \\
\hline & $\begin{array}{c}\text { Aralia nudicaulis \& } \\
\text { spp. }\end{array}$ & $\begin{array}{l}\text { Sarsasparilla } \\
\text { Wild ginseng }\end{array}$ & América do Norte & $\begin{array}{c}\text { Não possui propriedades } \\
\text { similares ao grupo dos } \\
\text { ginsengs }\end{array}$ \\
\hline & Echinopanax horridum & $\begin{array}{c}\text { Devils club } \\
\text { Alaskan ginseng } \\
\text { Rocky Mt. ginseng }\end{array}$ & $\begin{array}{l}\text { Encontrado em todo } \\
\text { norte da América do } \\
\text { Norte ocidental em } \\
\text { áreas úmidas }\end{array}$ & $\begin{array}{l}\text { Não possui propriedades } \\
\text { similares ao grupo dos } \\
\text { ginsengs. Planta medicinal } \\
\text { na cultura indígena }\end{array}$ \\
\hline \multirow[t]{9}{*}{$\begin{array}{l}\text { Falsos ginsengs } \\
\text { (outras famílias) }\end{array}$} & $\begin{array}{c}\text { Pfaffia paniculata e } \\
\text { pfaffia iresinoides } \\
\text { (família } \\
\text { Amaranthaceae) }\end{array}$ & $\begin{array}{c}\text { Suma } \\
\text { Brazilian ginseng } \\
\text { South American } \\
\text { ginseng }\end{array}$ & Brasil & $\begin{array}{l}\text { Não possui similaridade } \\
\text { química }\end{array}$ \\
\hline & $\begin{array}{l}\text { Whitania somnifera } \\
\text { (família Solanaceae) }\end{array}$ & $\begin{array}{l}\text { Ashwangandha } \\
\text { Ayurvedic ginseng } \\
\text { Indian ginseng } \\
\text { Winter cherry }\end{array}$ & Índia & $\begin{array}{l}\text { Não possui similaridade } \\
\text { química. Utilizado na } \\
\text { medicina ayurvédica }\end{array}$ \\
\hline & $\begin{array}{l}\text { Lepidium meyenii } \\
\text { (família Cruciferae) }\end{array}$ & $\begin{array}{c}\text { Maca } \\
\text { Ginseng of the Andes }\end{array}$ & $\begin{array}{l}\text { Nativo do Peru a mais } \\
\text { de } 12.000 \text { pés }\end{array}$ & $\begin{array}{c}\text { Não possui similaridade } \\
\text { química }\end{array}$ \\
\hline & $\begin{array}{c}\text { Rumex } \\
\text { hymenosepalus } \\
\text { (família } \\
\text { Polygonaceae) }\end{array}$ & $\begin{array}{l}\text { Wild red American } \\
\text { ginseng } \\
\text { Wild red desert } \\
\text { ginseng } \\
\text { Canaigre }\end{array}$ & Centro-sul dos EUA & $\begin{array}{l}\text { Não possui similaridade } \\
\text { química }\end{array}$ \\
\hline & $\begin{array}{l}\text { Pseudostellaria } \\
\text { heterophyla } \\
\text { (família } \\
\text { Caryophylaceae) }\end{array}$ & $\begin{array}{l}\text { Prince's ginseng } \\
\text { Tai zé shen }\end{array}$ & China & $\begin{array}{c}\text { Não possui similaridade } \\
\text { química }\end{array}$ \\
\hline & $\begin{array}{c}\text { Angelica sinensis } \\
\text { (família Umbelliferae) }\end{array}$ & $\begin{array}{l}\text { Women's ginseng } \\
\text { Dong quai } \\
\text { Dang gui ou Tang } \\
\text { kwai }\end{array}$ & China & $\begin{array}{c}\text { Não possui similaridade } \\
\text { química }\end{array}$ \\
\hline & $\begin{array}{c}\text { Codonopsis pilosula } \\
\text { (família } \\
\text { Campanulaceae) }\end{array}$ & $\begin{array}{l}\text { Dang shen } \\
\text { Bastard ginseng } \\
\text { Poor man's ginseng } \\
\text { False ginseng }\end{array}$ & China & $\begin{array}{l}\text { Considerado por muitos } \\
\text { como tendo efeitos } \\
\text { similares ao ginseng } \\
\text { asiático, porém muito mais } \\
\text { barato. Não possui } \\
\text { similaridade química }\end{array}$ \\
\hline & $\begin{array}{c}\text { Adenophora } \\
\text { polymorpha } \\
\text { (família } \\
\text { Campanulaceae) }\end{array}$ & False ginseng & China & $\begin{array}{c}\text { Não possui similaridade } \\
\text { química }\end{array}$ \\
\hline & $\begin{array}{l}\text { Caulophyllem } \\
\text { thalictroides } \\
\text { (família } \\
\text { Berberidaceae) }\end{array}$ & Blue ginseng & América do Norte & $\begin{array}{c}\text { Não possui similaridade } \\
\text { química }\end{array}$ \\
\hline
\end{tabular}

Fonte: British Columbia Ministry of Agriculture and Food 


\subsection{Compostos presentes na P.paniculata e ações farmacológicas}

As substâncias até o momento isoladas da P.paniculata são o ácido pfáfico, os pfafosídeos A, B, C, D, E e F, uma mistura de sitosterol e estigmasterol, seus glicosídeos estigmasteril- $\beta$-D-glucosídeo e sitosteril- $\beta$-D-glucosídeo, e alantoína.

Muitas das propriedades atribuídas à Pfaffia paniculata não têm comprovação científica e existem poucos trabalhos publicados com esta planta.

Os estudos já realizados com a P.paniculata demonstraram atividade antiinflamatória em camundongos (MAZZANTI et al., 1993) e analgésicas em ratos (OGA et al., 1987).

A atividade antitumoral da P.paniculata foi avaliada em modelo de tumor transplantável (tumor de Ehrlich), em que foi observada redução no volume ascítico dos animais tratados oralmente com a raiz pulverizada (MATSUZAKI et al., 2003). Em outro estudo foi avaliada a incidência de linfomas espontâneos em camundongos causados pelo vírus recombinante de leucemia murina (MuLV). Os animais foram tratados por via oral por 24 semanas, sendo observada redução do volume tumoral nos animais tratados com a planta. Além disso, houve diminuição da proliferação do vírus MuLV após a primeira semana de tratamento com a raiz. Em outro ensaio do mesmo trabalho, animais com linfoma tímico receberam injeção intratumoral de extrato de timo de animais tratados com P.paniculata (isento de células). Estes animais tiveram um aumento de sobrevida em relação aos que não receberam o extrato. Os pesquisadores sugerem um envolvimento do sistema imunológico não específico e imunidade celular na resposta do hospedeiro ao tumor (WATANABE et al., 2000). 
O efeito direto sobre células tumorais deve ser considerado, já que a P.paniculata possui em sua composição compostos com atividade antineoplásica observada in vitro. O ácido pfáfico e os pfafosídeos A, C, D, E e F demonstraram efeito inibitório sobre o crescimento de células do melanoma murino B-16 em cultura (NAKAl et al., 1984; NISHIMOTO et al., 1984; TAKEMOTO et al., 1983)

Outras pesquisas enfocaram os efeitos da P.paniculata na esfera reprodutiva. A administração de extrato etanólico de P.paniculata normalizou a motivação e performance de ratos impotentes, porém não aumentou a atividade sexual de animais normais (potentes). Isto indica um possível efeito sobre o sistema nervoso central, normalizando o balanço de neuropeptídeos e neurotransmissores envolvidos no comportamento sexual dos animais (ARLETTI et al.,1999). A P.paniculata também possui fitoesteróides, e estes parecem ter a capacidade de aumentar os níveis dos hormônios sexuais. Camundongos tratados por via oral com a raiz pulverizada da P.paniculata tiveram um aumento significativo nos níveis de estradiol$17 \beta$, progesterona e testosterona (OSHIMA; YEUNHWA, 2003)

A $P$. paniculata também é utilizada para aliviar os sintomas da anemia falciforme. Ballas (2000) demonstrou que o tratamento com extrato de P.paniculata em hemácias provenientes de pacientes com anemia falciforme normaliza sua conformação e melhora as propriedades reológicas e hidratação das hemácias. 


\subsection{Câncer e busca de novos agentes}

As informações etnofarmacológicas de uma planta constituem um ponto de partida importante para a descoberta de novos agentes terapêuticos. O uso popular de uma planta para o tratamento de doenças é um indicativo da presença de compostos bioativos com uso potencial na clínica médica. Muitas drogas utilizadas atualmente foram desenvolvidas a partir do isolamento de substâncias presentes em plantas (MANS; ROCHA; SCHWARTSMANN, 2000; PEZZUTO, 1997)

Exemplos de drogas citotóxicas descobertas a partir de compostos presentes em plantas e utilizadas no tratamento do câncer são: Vinblastina e Vincristina (Catharanthus roseus); Etoposídeo e Tenitoposídeo (Podophyllum peltatum; P.emodi); Paclitaxel e Docetaxel (Taxus brevifolia); Irinotecan, Topotecan, 9Aminocampothecin e 9-Nitrocamptothecin (Camptotheca acuminata). Outras drogas que estão em fase experimental são: Homoharringtonine (Harringtonia cephalotaxus); 4-Ipomeanol (Ipomeaca batatas); Elliptinium (Bleekeria vitensis); Flavopiridol (Amoora rohituka; Dysoxylum binectariferum) (MANS; ROCHA; SCHWARTSMANN, 2000).

Os efeitos medicinais benéficos de compostos originários de plantas resultam de combinações de produtos secundários do metabolismo vegetal. Estes produtos secundários possuem funções importantes na ecofisiologia da planta, tendo implicações na sobrevivência individual. Estão envolvidos na proteção contra agressores externos (ataques de herbívoros, insetos, doenças, radiação solar, alterações físico-químicas do ambiente), atração de agentes polinizadores e simbiontes, e possivelmente agem em nível celular como reguladores do 
crescimento da planta, modulam a expressão gênica e agem na sinalização intracelular (BRISKIN, 2000).

Dentre os produtos secundários produzidos por uma planta, está uma classe de compostos químicos denominada de saponinas. As saponinas são glicosídeos de esteróides ou terpenos policíclicos. Esse tipo de estrutura possui uma parte com característica lipofílica (aglicona hidrofóbica que pode ser um triterpeno ou um esteróide) e outra parte hidrofílica composta de açúcares (glicose, galactose, ácido glucurônico, xilose, rhamanose, ou metilpentose) (FRANCIS et al., 2002; SCHENKEL et al., 2002). O comportamento anfifílico das saponinas e a capacidade de formar complexos com esteróides, proteínas e fosfolipídeos de membranas determinam um número variado de propriedades biológicas para essas substâncias (SCHENKEL et al., 2002).

As saponinas ocorrem naturalmente em muitas espécies de plantas e podem ser consideradas como parte de seu sistema de defesa. São conhecidas diversas saponinas com ação antimicrobiana, antifúngica e pela proteção contra ataques de insetos. A grande complexidade da estrutura das saponinas é decorrente da variabilidade da estrutura da aglicona, a natureza das cadeias laterais e a posição em que elas estão ligadas à estrutura aglicona. Muitos efeitos biológicos das saponinas, como a permeabilização de membranas, propriedades imunoestimulantes, hipocolesterêmicas e antineoplásicas estão sendo estudadas (FRANCIS et al., 2002).

A atividade biológica de saponinas (ginsenosídeos) contidas em ginsengs do gênero Panax tem sido extensivamente estudada. Muitos dos ginsenosídeos já isolados apresentam atividade antineoplásica por vários mecanismos diferentes (ATTELE; WU; YUAN, 1999; CHANG et al., 2003; SHIBATA, 2001). 
Por suas propriedades similares aos esteróides, os ginsenosídeos são capazes de atravessar as membranas das células e chegar a receptores citoplasmáticos ou nucleares, desencadeando os efeitos observados sobre as células (ATTELE; WU; YUAN, 1999).

Da mesma maneira como está ocorrendo com o Panax $s p$, um estudo mais aprofundado dos compostos existentes na P.paniculata poderia revelar outros componentes de interesse.

O teor de saponinas brutas encontrado na P.paniculata está em torno de $11 \%$ (OLIVEIRA; AKISUE; AKISUE, 1980). As saponinas identificadas na P.paniculata são os pfafosídeos $A, B, C, D, E$ e $F$, e o ácido pfáfico, produto hidrolítico dos pfafosídeos. Estes apresentaram atividade antitumoral in vitro, com exceção do pfafosídeo B (NAKAl et al., 1984; NISHIMOTO et al., 1984; TAKEMOTO et al., 1983).

Um dos problemas na terapêutica do câncer é o desenvolvimento de resistência das células cancerosas às drogas utilizadas durante o tratamento. Deste modo, pesquisas de novos agentes antineoplásicos com novos mecanismos de ação se fazem necessários.

A pesquisa de novos agentes antineoplásicos realizada em larga escala por algumas instituições, como o $\mathrm{NCl}$ (National Cancer Institute, EUA) envolve um planejamento elaborado, alta tecnologia e softwares que ajudam a identificar os compostos com maior potencial para o desenvolvimento de uma nova droga (SCHILSKY; MILANO; RATAIN, 1996; TEICHER, 1997). Este esquema permite o screening de muitos compostos em curto espaço de tempo. Entretanto, da mesma maneira que é possível a avaliação de muitas substâncias ao mesmo tempo, outras tantas com potencial terapêutico passam despercebidas. Daí a importância dos 
estudos conduzidos principalmente nas universidades, muitas vezes em associações com outras instituições, que possibilitam um estudo mais aprofundado dos compostos com potencial terapêutico.

\subsection{Câncer de mama}

Cerca de um milhão de casos novos de câncer de mama são diagnosticados ao ano, mundialmente. Este é o segundo tipo de câncer de maior prevalência entre a população mundial, estando atrás do câncer de pulmão (1,2 milhões de casos novos), e é o de maior prevalência entre as mulheres (INCA, 2003). No Brasil, o câncer de mama é o que mais causa mortes entre as mulheres. Dos 467.440 novos casos de câncer com previsão de serem diagnosticados em 2005, o câncer de mama foi o segundo mais incidente entre a população feminina, sendo responsável por 49.470 casos novos (INCA, 2005).

Em alguns países desenvolvidos como Estados Unidos, Canadá, Reino Unido, Holanda, Dinamarca e Noruega, têm se observado um aumento na incidência do câncer de mama acompanhado de redução de mortalidade, que está relacionado ao diagnóstico precoce e tratamento adequado. Em outros países, como no Brasil, existe um retardo no diagnóstico e na instituição da terapêutica adequada (INCA, 2004).

A incidência de câncer de mama aumenta de acordo com a idade, alcançando o pico entre a faixa etária de 65 a 70 anos. Seu prognóstico é relativamente bom se diagnosticado nos estádios iniciais. Na população mundial, a sobrevida média após cinco anos é de 61\% (INCA, 2003), porém segundo o Hospital do Câncer em São 
Paulo (2005), setenta por cento dos casos de câncer de mama no Brasil são diagnosticados tardiamente, o que dificulta a cura definitiva.

Alguns fatores podem contribuir para o risco do desenvolvimento de câncer de mama. Os riscos são listados a seguir, de acordo com o Projeto Diretrizes, elaborado pela Associação Médica Brasileira e Conselho Federal de Medicina, para auxiliar a tomada de decisão de médicos em relação às suas pacientes:

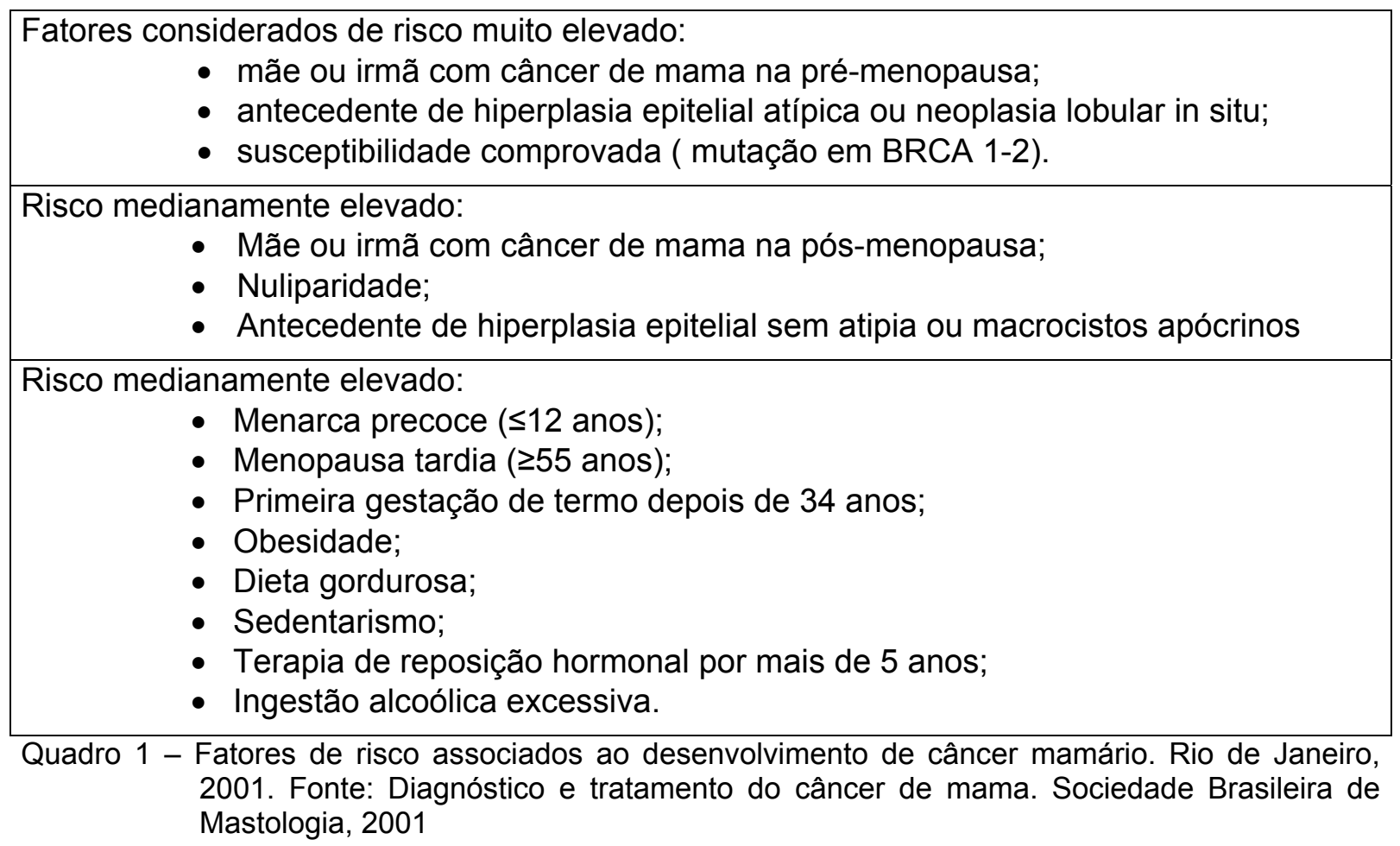

Os tratamentos disponíveis incluem cirurgia, radioterapia e quimioterapia com os protocolos individualizados para cada paciente. 


\section{OBJETIVOS}

\subsection{Objetivo Geral}

Determinar os efeitos dos extratos etanólico, butanólico e aquoso de $P$. paniculata sobre o crescimento de linhagens de células mamárias humanas em cultura.

\subsection{Objetivos Específicos}

- Avaliar a citotoxicidade em células tratadas com extratos etanólico, butanólico ou aquoso da Pfaffia paniculata por meio da leitura de densidade óptica.

- Detectar a morte celular por meio da técnica fluorescente da laranja de acridina e brometo de etídio de células tratadas com extrato butanólico.

- Avaliar a proliferação celular (fase $S$ do ciclo celular) de células tratadas com extrato butanólico, por meio da marcação de núcleos positivos para a incorporação da bromodeoxiuridina (BrdU).

- Avaliar as alterações ultraestruturais após o tratamento das células MCF-7 com extrato butanólico. 


\section{MATERIAL E MÉTODOS}

\subsection{Linhagem de células tumorais mamárias humanas MCF-7 e SKBR-3}

As células MCF-7 e SKBR-3 inicialmente estabelecidas na década de 70 a partir de células tumorais provenientes de efusão pleural, são originadas de tumor metastático de câncer de mama (RONNOV-JESSEN; PETERSEN; BISSEL; 1996; SOULE et al, 1973). As células MCF-7 apresentam receptor para estrógeno (LEVENSON; JORDAN, 1997), enquanto as células SKBR-3 não possuem (RONNOV-JESSEN; PETERSEN; BISSEL; 1996,). Ambas são tumorigênicas quando implantadas em camundongos nude, porém são pouco invasivas (ZAJCHOWSKI et al., 2001). Estas células podem ser adquiridas diretamente na ATCC (American Type Culture Collection, EUA).

\subsection{Raízes de Pfaffia paniculata}

As raízes de $P$. paniculata foram gentilmente cedidas pelo Prof. Gokithi Akisue, e mantidas em sacos plásticos selados a vácuo até o momento do preparo do extrato e resíduos. A exsicata $\left(n^{\circ} 37411\right)$ desse espécime encontra-se depositada no Herbário Goro Hashimoto. 


\subsection{Obtenção do extrato e resíduos de Pfaffia paniculata}

O preparo do extrato e resíduos das raízes de $P$. paniculata foi realizado no Instituto Biológico, sob supervisão da $\mathrm{Dr}^{\mathrm{a}}$. Mitsue Haraguchi, de acordo com protocolo estabelecido previamente (HARAGUCHI et al.,2000; NISHIMOTO et al., 1984;). Resumidamente, as raízes pulverizadas foram misturadas com etanol $95 \%$ (0,5 $\mathrm{Kg}$ de raiz/ $\mathrm{L}$ álcool), assim permanecendo por 3 a 4 dias. $\mathrm{O}$ extrato etanólico obtido foi concentrado em rotaevaporador sob pressão reduzida, à temperatura de $55^{\circ} \mathrm{C}$, para a eliminação do solvente. Parte deste extrato foi dissolvido em água, e a solução aquosa resultante fracionada por partição com butanol saturado com água em fração butanólica e fração aquosa. A fração aquosa foi liofilizada. A fração butanólica foi concentrada em rotaevaporador sob pressão reduzida, à temperatura de $55^{\circ} \mathrm{C}$, para a eliminação do solvente, sendo posteriormente mantida em dessecador até atingir peso constante. Os resíduos aquoso e butanólico obtidos foram mantidos em freezer $\mathrm{a}-20^{\circ} \mathrm{C}$ até o momento da utilização.

Para o uso nos experimentos, os extratos foram inicialmente diluídos em tampão fosfato (PBS) e filtrados para garantir a esterilidade da solução. Foram utilizados filtros para seringa com membrana PES de porosidade de $0,22 \mu \mathrm{m}$ (Millipore). As concentrações iniciais foram de $10 \mathrm{mg} / \mathrm{ml}$ para os extratos etanólico e butanólico, e $100 \mathrm{mg} / \mathrm{ml}$ para o extrato aquoso. As diluições finais foram feitas em meio R-10 estéril (RPMI-1640 acrescido de 10\% de soro fetal bovino). 


\subsection{Manutenção e tratamento da cultura de células}

Os efeitos dos extratos de P.paniculata foram avaliados sobre o crescimento de células mamárias tumorais humanas de linhagens estabelecidas. Neste trabalho, foram utilizadas as linhagens de adenocarcinoma mamário humano MCF-7 e SKBR3.

Os experimentos e a manutenção das culturas de células foram realizados no Laboratório de Imunologia de Tumores (Instituto de Ciências Biomédicas IV/USPSP), de responsabilidade do Prof. Dr. José Alexandre Marzagão Barbuto.

As células foram mantidas em cultura em meio RPMI-1640 (Gibco) acrescido de $10 \%$ de soro fetal bovino (Gibco), em estufa umidificada com atmosfera contendo $5 \%$ de $\mathrm{CO}_{2}$ a $37^{\circ} \mathrm{C}$.

\subsection{Curva de crescimento}

Para determinar a quantidade de células necessária para os experimentos, foi realizada uma curva de crescimento de cada uma das linhagens com diferentes concentrações de células e tempos de incubação de 24,48 ou 72 horas.

As células foram plaqueadas em duplicata $(100 \mu \mathrm{l} /$ poço) em placas de 96 poços de fundo chato estéril (Corning) em diferentes concentrações, e incubadas por períodos de 24, 48 ou 72 horas. Após o período de incubação, as células foram coradas com $10 \mu \mathrm{l} /$ poço de cristal violeta $(0,5 \%$ de cristal violeta e $30 \%$ ácido acético) 
por 10 minutos. As placas foram lavadas em água corrente para a retirada de células não aderidas e colocadas para secar. Depois de secas, foram adicionados $100 \mu \mathrm{l} /$ poço de metanol e a leitura da densidade óptica feita a $570 \mathrm{~nm}$ em espectrofotômetro (Versa Max, Molecular Devices).

\subsection{Ensaio de citotoxicidade}

A metodologia para a avaliação dos efeitos dos extratos de P.paniculata sobre o crescimento das células MCF-7 e SKBR-3 em cultura foi obtido a partir do protocolo utilizado pelo $\mathrm{NCl}$ (National Cancer Institute, EUA), na triagem de compostos com potencial antineoplásico, modificado para as nossas condições.

As células foram plaqueadas $(100 \mu \mathrm{l} /$ poço) em placas de 96 poços de fundo chato estéril (Corning) em concentração de $5 \times 10^{4}$ células $/ \mathrm{ml}$ e pré-incubados por 24 horas em estufa a $37^{\circ} \mathrm{C}\left(5 \%\right.$ de $\mathrm{CO}_{2}$ e $100 \%$ umidade relativa). Após as 24 horas, as células foram tratadas com $100 \mu \mathrm{l} /$ poço de diferentes diluições dos extratos, duas vezes concentrados, a fim de se alcançar a concentração final desejada (1ng$1 \mathrm{mg} / \mathrm{ml}$ ). As células foram incubadas por mais 48 horas (ou 24 horas, de acordo com

o tempo de tratamento). A coloração das células foi feita adicionando-se $20 \mu \mathrm{l} /$ poço de cristal violeta, permanecendo por 10 minutos, sendo então lavada. A leitura foi feita em espectrofotômetro a 570nm.

Para determinar o efeito do tratamento sobre o crescimento das foi utilizada a seguinte fórmula: 


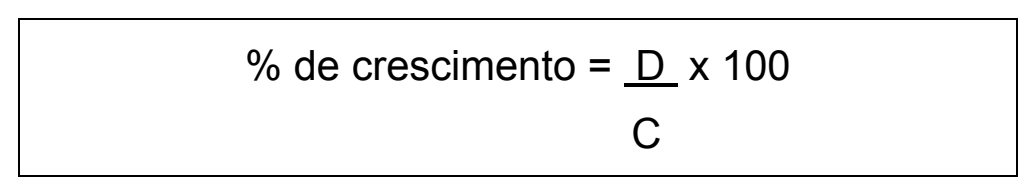
D- densidade óptica média de cada tratamento
C- densidade óptica média do controle

\subsection{Tratamento tipo pulso}

O tratamento do tipo pulso foi feito com este protocolo, alterando-se o tempo de tratamento (1 hora). Após o período de tratamento com os extratos, o sobrenadante foi retirado e substituído por meio R-10, permanecendo em incubação pelo tempo restante. Em todos os experimentos, cada diluição foi feita em sextuplicata.

\subsection{Detecção de morte celular utilizando laranja de acridina e brometo de etídio}

As células MCF-7 foram plaqueadas (100 $\mu \mathrm{l} /$ poço) em placas de 96 poços de fundo chato estéril (Corning) em concentração de $5 \times 10^{4}$ células/ml e pré-incubados por 24 horas em estufa a $37^{\circ} \mathrm{C}\left(5 \%\right.$ de $\mathrm{CO}_{2}$ e $100 \%$ umidade relativa). Após as 24 horas as células foram tratadas com $100 \mu \mathrm{l} /$ poço de diferentes diluições dos extratos, duas vezes concentrados, a fim de se alcançar a concentração final desejada (10 a 
$1000 \mu \mathrm{g} / \mathrm{mL}$ ). As células foram incubadas por mais 1, 4, 24 ou 48 horas. Após o período de incubação, o sobrenadante dos poços foi retirado e recolocado $25 \mu \mathrm{L}$ do mesmo sobrenadante em cada poço. A verificação de células mortas e vivas após o tratamento com extrato butanólico foi feita adicionando-se $1 \mu \mathrm{L}$ de solução contendo laranja de acridina $(100 \mu \mathrm{g} / \mathrm{ml})$ (Sigma) e brometo de etídio $(100 \mu \mathrm{g} / \mathrm{ml})$ (Sigma) na proporção de 1:1, para cada $25 \mu \mathrm{L}$ de meio contendo as células (SPECTOR, 1998). A visualização foi feita em microscópio de fluorescência Nikon Eclipse E800 com filtro para FITC/Texas Red, logo após a adição da solução. As imagens foram obtidas com o auxílio do software Image-Pro Plus versão 4.5 (Media CyberneticsEUA).

\subsection{Quantificação da fração proliferativa por meio da marcação de núcleos positivos para BrdU}

O procedimento para a marcação das células que incorporaram a bromodeoxiuridina foi feito de acordo com o protocolo estabelecido por Muir, Varon e Manthorpe (1990).

As células foram pré-incubadas em placa de 96 poços de fundo chato estéril ( $5 \times 10^{3}$ células/poço), por 4 horas, em estufa com atmosfera contendo $5 \%$ de $\mathrm{CO}_{2} \mathrm{e}$ saturada de água a $37^{\circ} \mathrm{C}$. Após o período de pré-incubação, as células foram tratadas com extrato butanólico em concentração final de $500 \mu \mathrm{g} / \mathrm{ml}, 750 \mu \mathrm{g} / \mathrm{ml}$ ou $1 \mathrm{mg} / \mathrm{ml}$, permanecendo por mais 48 horas. Uma hora antes do término deste período, as células receberam 5-bromo2'-deoxiuridina (BrdU, Sigma) em 
concentração final de $10 \mu \mathrm{M}$. Após o período de incubação, o meio foi aspirado e os poços lavados com $200 \mu \mathrm{l} /$ poço de solução Hanks. As células foram fixadas trocando-se a solução Hanks por $200 \mu \mathrm{l} /$ poço de etanol $70 \%$ por 20 minutos em temperatura ambiente. Os poços foram então lavados com água e o DNA desnaturado com $100 \mu \mathrm{l} /$ poço de $\mathrm{HCl} 2 \mathrm{M}$ por 10 minutos a $37^{\circ} \mathrm{C}$. $\mathrm{O} \mathrm{HCl}$ foi aspirado e a acidez residual neutralizada com tampão borato $(0,1 \mathrm{M} \mathrm{pH}$ 9). Os poços foram lavados com tampão fosfato (PBS) e tratados com $50 \mu$ le tampão de bloqueio (PBS contendo $0,1 \%$ Triton $\mathrm{X}-100$ e azida/albumina) por 15 minutos a $37^{\circ} \mathrm{C}$. O anticorpo monoclonal de camundongo anti-BrdU (kit Amersham Biosciences) diluído em tampão bloqueio (1:1000) foi adicionado ( $50 \mu \mathrm{l} /$ poço) e permaneceu por 60 minutos a $37^{\circ} \mathrm{C}$. Os poços foram lavados três vezes com PBS contendo $0,1 \%$ de Triton. Em seguida aplicou-se 0 anticorpo secundário anti-imunoglobulinas de

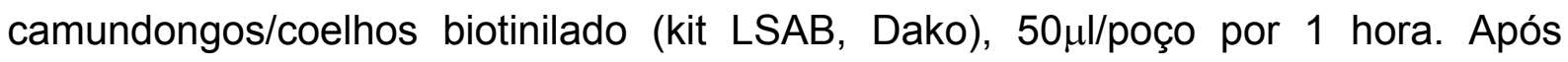
lavagens com PBS/Triton, aplicou-se o complexo estreptavidina-biotina-peroxidase (kit LSAB, Dako), $50 \mu \mathrm{l} /$ poço por 1 hora. Os poços foram lavados com PBS/Triton e finalmente lavados com PBS. A revelação foi feita com a adição de PBS contendo 0,025\% de diaminobenzidina (DAB) e 0,02\% de peróxido de hidrogênio. A reação foi monitorada em microscópio de luz e interrompida lavando-se a placa com água. Imagens de cada poço contendo as células marcadas foram obtidas para quantificação de núcleos positivos para BrdU, com a ajuda do programa Image-Pro Plus. 


\subsection{Verificação de alterações subcelulares (microscopia eletrônica de transmissão)}

As células MCF-7 $\left(5 \times 10^{5}\right.$ células/poço) foram plaqueadas em placas de Petri de 35mm estéreis contendo lamínulas em seu interior. Após 24 horas de préincubação em estufa a $37^{\circ} \mathrm{C}\left(5 \%\right.$ de $\mathrm{CO}_{2}$ e $100 \%$ umidade relativa), as células foram tratadas com extrato butanólico, em concentração final de $500 \mu \mathrm{g} / \mathrm{ml}$ ou $1 \mathrm{mg} / \mathrm{ml}$. O tratamento controle foi feito com R-10. As células foram incubadas por mais 48 horas. Após o período final de incubação, o meio foi aspirado, as placas contendo as lamínulas foram cuidadosamente lavadas com PBS a $37^{\circ} \mathrm{C}$ e finalmente fixadas com glutaraldeído $2,5 \%$, por no mínimo 2 horas.

Após a fixação, o material foi preparado para inclusão. As lamínulas foram lavadas três vezes com solução salina $0,9 \%$, sendo então colocada solução de ósmio $1 \%$, que permaneceu por 24 horas. As lamínulas foram lavadas três vezes com solução salina $0,9 \%$, após o qual permaneceram por 24 horas em solução de acetato de uranila $0,5 \%$. A seguir foram realizadas as etapas de desidratação, inclusão e emblocamento.

A desidratação do material foi feita com quantidades crescentes de acetona em água tridestilada (Tabela 3).

Tabela 3 - Protocolo de desidratação do material.

\begin{tabular}{ccc}
\hline $\begin{array}{c}\text { Concentração de acetona } \\
\text { em água tridestilada }\end{array}$ & Número de banhos & Tempo de permanência \\
\hline $30 \%$ & um & 10 minutos \\
$50 \%$ & um & 10 minutos \\
$70 \%$ & um & 10 minutos \\
$90 \%$ & um & 10 minutos \\
$100 \%$ & três & 10 minutos cada banho \\
\hline
\end{tabular}


O processo de substituição e inclusão é feito com concentrações crescentes de resina de inclusão (Araldite 502) em acetona, sob agitação (Tabela 4).

Tabela 4 - Proporção acetona: resina de inclusão

\begin{tabular}{cc}
\hline Proporção acetona:resina de inclusão & Tempo de permanência \\
\hline $3: 1$ & 1 hora \\
$1: 1$ & 1 hora \\
$1: 3$ & 1 hora \\
\hline
\end{tabular}

Após a última troca, o material foi colocado em resina para inclusão pura, permanecendo em estufa a $37^{\circ} \mathrm{C}$ por uma hora. Fôrmas de inclusão foram preenchidas com resina e viradas sobre as lamínulas processadas. O material permaneceu em estufa a $60^{\circ} \mathrm{C}$ por 72 horas. As lamínulas foram retiradas do material emblocado, mergulhando-se os blocos em nitrogênio líquido. Foram obtidos cortes ultrafinos para observação em microscópio eletrônico de transmissão.

\subsection{Análise estatística}

Os tratamentos foram avaliados pela Análise de Variância (ANOVA) de uma via. O pós-teste foi feito com o teste de Dunnett. Foram consideradas significantes as análises que apresentaram um nível de significância $p<0,05$. Os resultados foram expressos como média \pm desvio padrão. 


\section{RESULTADOS}

\subsection{Rendimento dos extratos}

A partir de $11,871 \mathrm{~kg}$ da raiz pulverizada foram obtidos $358,33 \mathrm{~g}$ de resíduo etanólico (3,02\%). De 306,44g do resíduo etanólico foram obtidos $45 \mathrm{~g}$ de resíduo butanólico $(14,68 \%)$ e $136 \mathrm{~g}$ de resíduo aquoso $(44,38 \%)$.

\subsection{Curva de crescimento}

As curvas de crescimento das linhagens MCF-7 e SKBR-3 foram realizadas para determinar quantidade ideal de células a serem plaqueadas nos experimentos. A quantidade de células foi estabelecida em uma faixa em que fosse possível a leitura das diferenças na densidade óptica e que o crescimento não excedesse a área de crescimento dos poços. O número excessivo de células plaqueadas pode ser observado pela queda dos valores da densidade óptica. A faixa escolhida para os experimentos variou de $2 \times 10^{3}$ a $2 \times 10^{4}$ células/poço dependendo do tempo de incubação. 


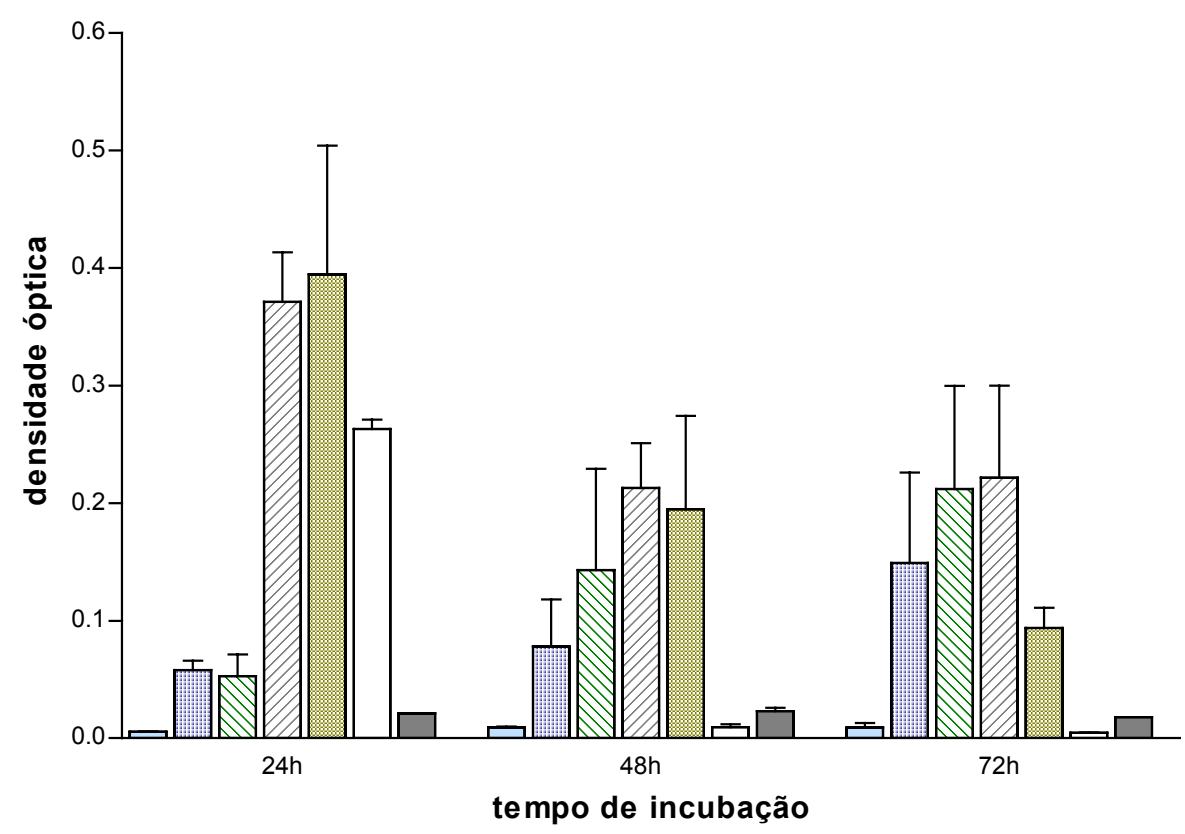

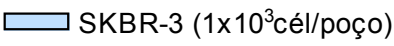

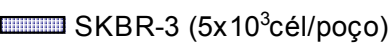

SKBR-3 (1×104cél/poço)

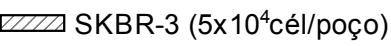

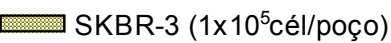

$\square$ SKBR-3 (5x1050él/poço)

SKBR-3 (1×106 cél/poço)

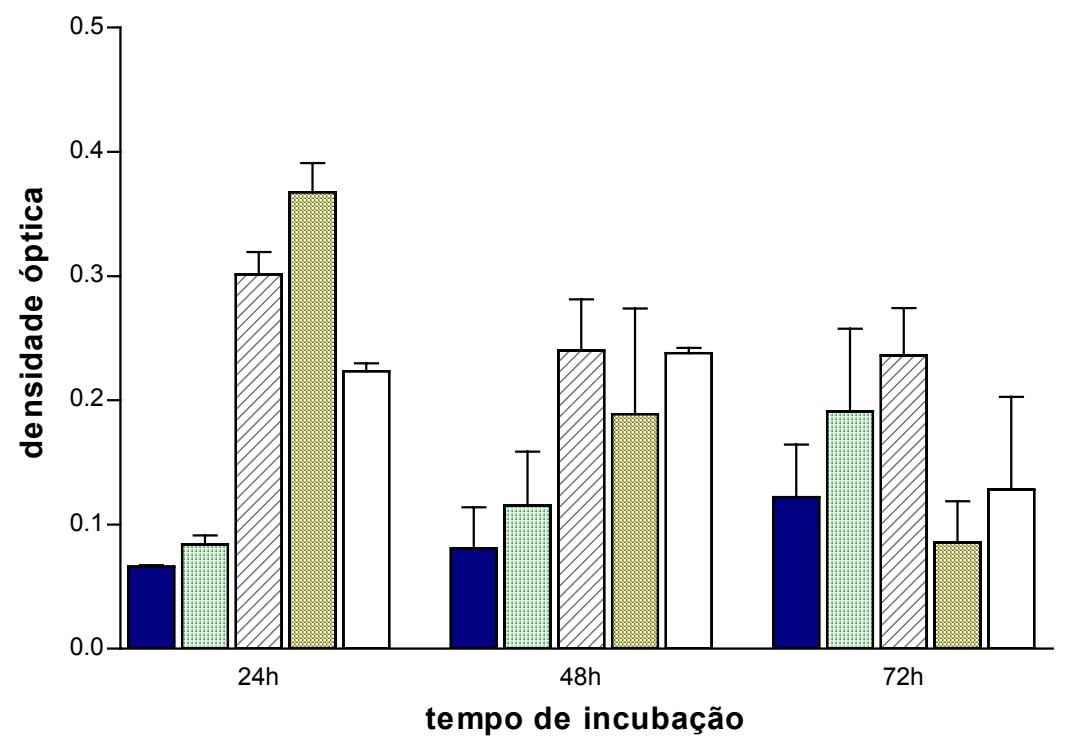

B

Figura 2 - Curvas de crescimento das linhagens SKBR-3 (A) e MCF-7 (B) com diferentes concentrações de células em diferentes tempos de incubação. 


\subsection{Ensaio de citotoxicidade}

A porcentagem de crescimento das células MCF-7 após o tratamento com o extrato etanólico não mostrou diferença estatística entre as células tratadas e as células não tratadas (Figura 3, ANOVA P=0,7278). Nas células SKBR-3, observouse redução de crescimento somente com a concentração de $10 \mathrm{ng} / \mathrm{mL}$ de extrato etanólico (figura 3B, ANOVA $\mathrm{P}=0,0183$; teste Dunnett, $\mathrm{P}<0,01$ ).

O tratamento com o extrato aquoso nas linhagens SKBR-3 e MCF-7 não produziu efeitos sobre o crescimento celular (Figura 4, ANOVA $P=0,1245$ para SKBR-3 e ANOVA $P=0.6316$ para MCF-7).

O tratamento com $1000 \mu \mathrm{g} / \mathrm{mL}$ do extrato butanólico causou redução no crescimento celular nas linhagens MCF-7 (Figura 5A, ANOVA $P<0,0001 ; P<0,01$ ) e SKBR-3 (Figura 5B, ANOVA $P<0,0001 ; \mathrm{P}<0,01$ ). Na linhagem SKBR-3 também houve redução do crescimento com $1 \mathrm{ng} / \mathrm{mL}$ (Figura 5B, $\mathrm{P}<0,05$ ) e aumento do crescimento com $100 \mu \mathrm{g} / \mathrm{mL}$ (Figura 5, P<0,05).

Para estabelecer a partir de qual concentração o extrato butanólico apresenta diferença estatística no crescimento celular, as células foram tratadas com diluições de 100 a $900 \mu \mathrm{g} / \mathrm{ml}$. A partir da concentração de $400 \mu \mathrm{g} / \mathrm{ml}$ houve diminuição estatisticamente significante do crescimento celular nas células MCF-7 (Figura 6A, ANOVA P<0,0001). Nas células SKBR-3 a concentração inibitória foi alcançada com $500 \mu \mathrm{g} / \mathrm{ml}$ do extrato butanólico (Figura 6B, ANOVA $\mathrm{P}<0,0001$ ).

Também foi realizado um tratamento tipo pulso, em que as células são tratadas por 1 hora, após o qual o meio contendo os extratos é retirado e substituído por meio de cultura normal. 
Os resultados referentes ao tratamento com o extrato etanólico não mostraram nenhuma diferença estatística na linhagem MCF-7 (Figura 7A, ANOVA $P=0,3201$ ) e na linhagem SKBR-3 (Figura 7B, ANOVA $P=0,5573$ ). O tratamento com o extrato butanólico não apresentou efeito inibitório no crescimento das células MCF7 (Figura 8A, ANOVA P=0,4520), porém nas células SKBR-3, a concentração de $1 \mu \mathrm{g} / \mathrm{ml}$ foi capaz de estimular o crescimento celular (Figura 8B, ANOVA P=0.1415; teste Dunnett $P<0,05)$. Já o extrato aquoso parece ter efeito estimulatório sobre o crescimento das células MCF-7, a partir da concentração de 10ng/mL (Figura 9A, ANOVA $P<0,0001)$ 

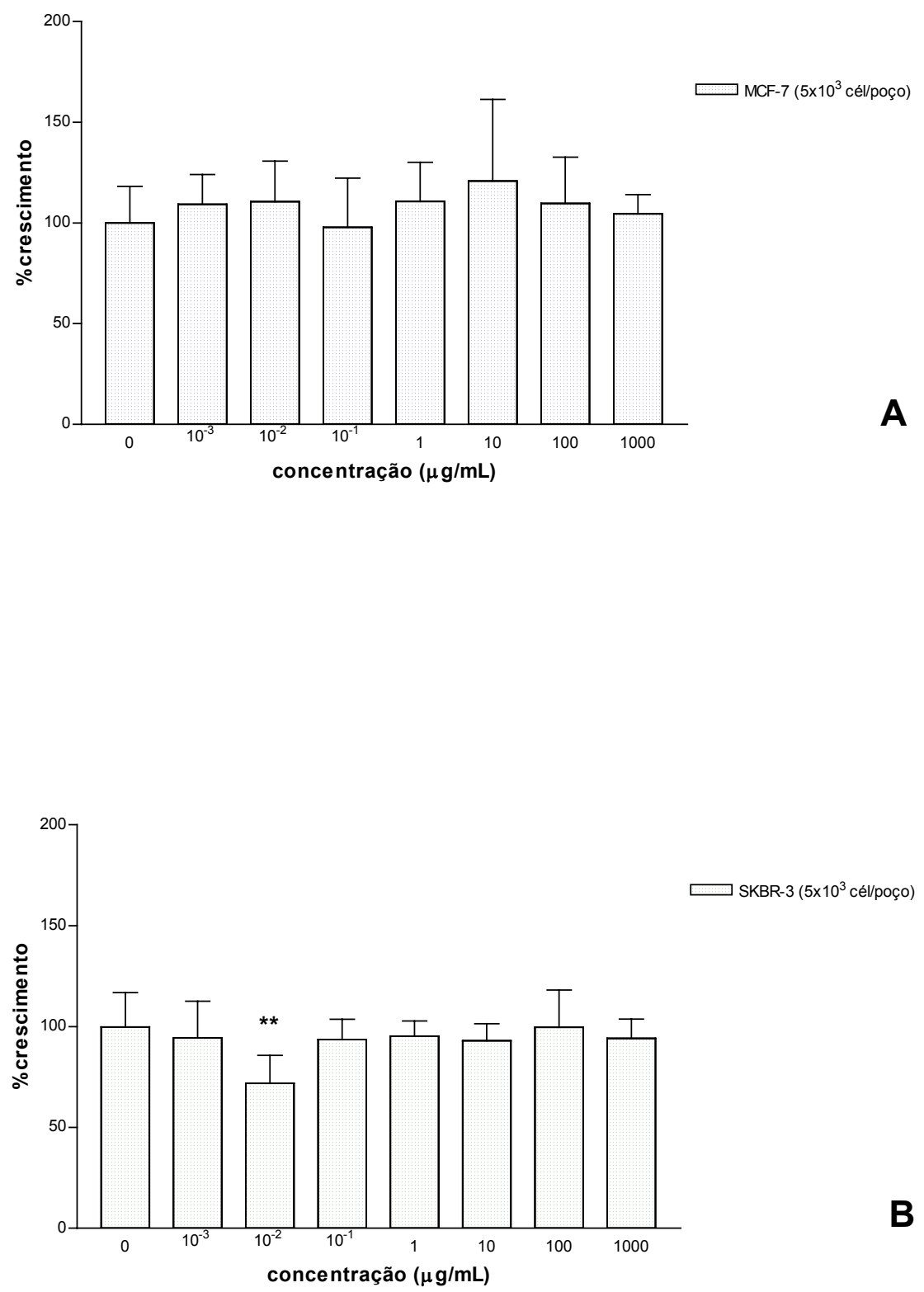

Figura 3 - Crescimento das células MCF-7 (A) e SKBR-3 (B) após 48 horas de tratamento com extrato etanólico. $O$ tratamento das células MCF-7 não mostrou diferença estatística. A linhagem SKBR-3 apresentou crescimento celular inferior com a concentração de $10 \mathrm{ng} / \mathrm{mL}$ de extrato etanólico. 


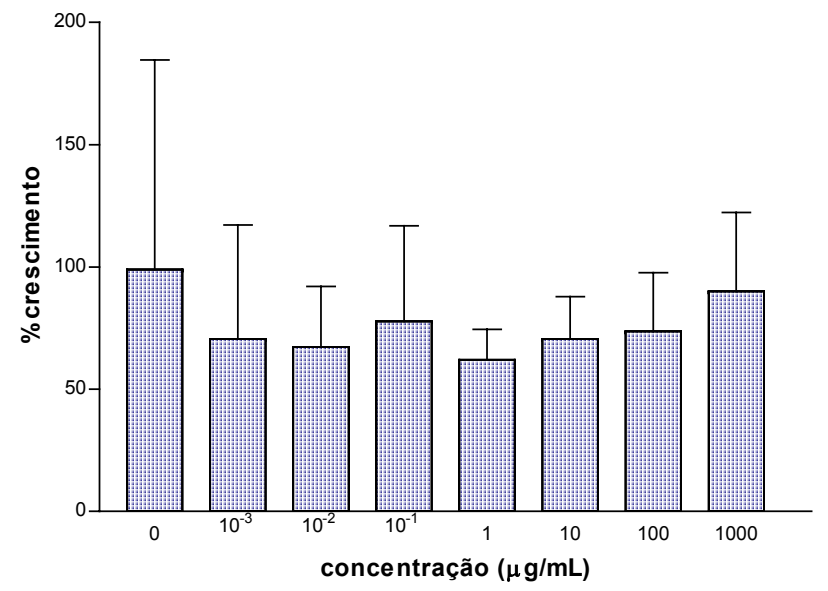

—MCF-7 $\left(2 \times 10^{3}\right.$ cél/poço $)$

A

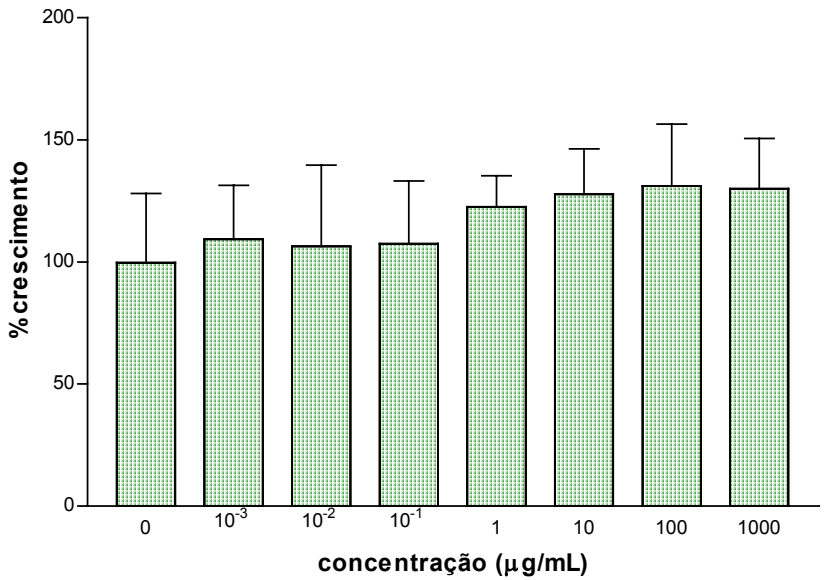

SKBR-3 $\left(5 \times 10^{3}\right.$ cél/poço $)$

Figura 4 - Crescimento das células MCF-7 (A) e SKBR-3 (B) após 48 horas de tratamento com extrato aquoso. Não há diferença estatisticamente significante com o tratamento nas células MCF-7 e SKBR-3. 

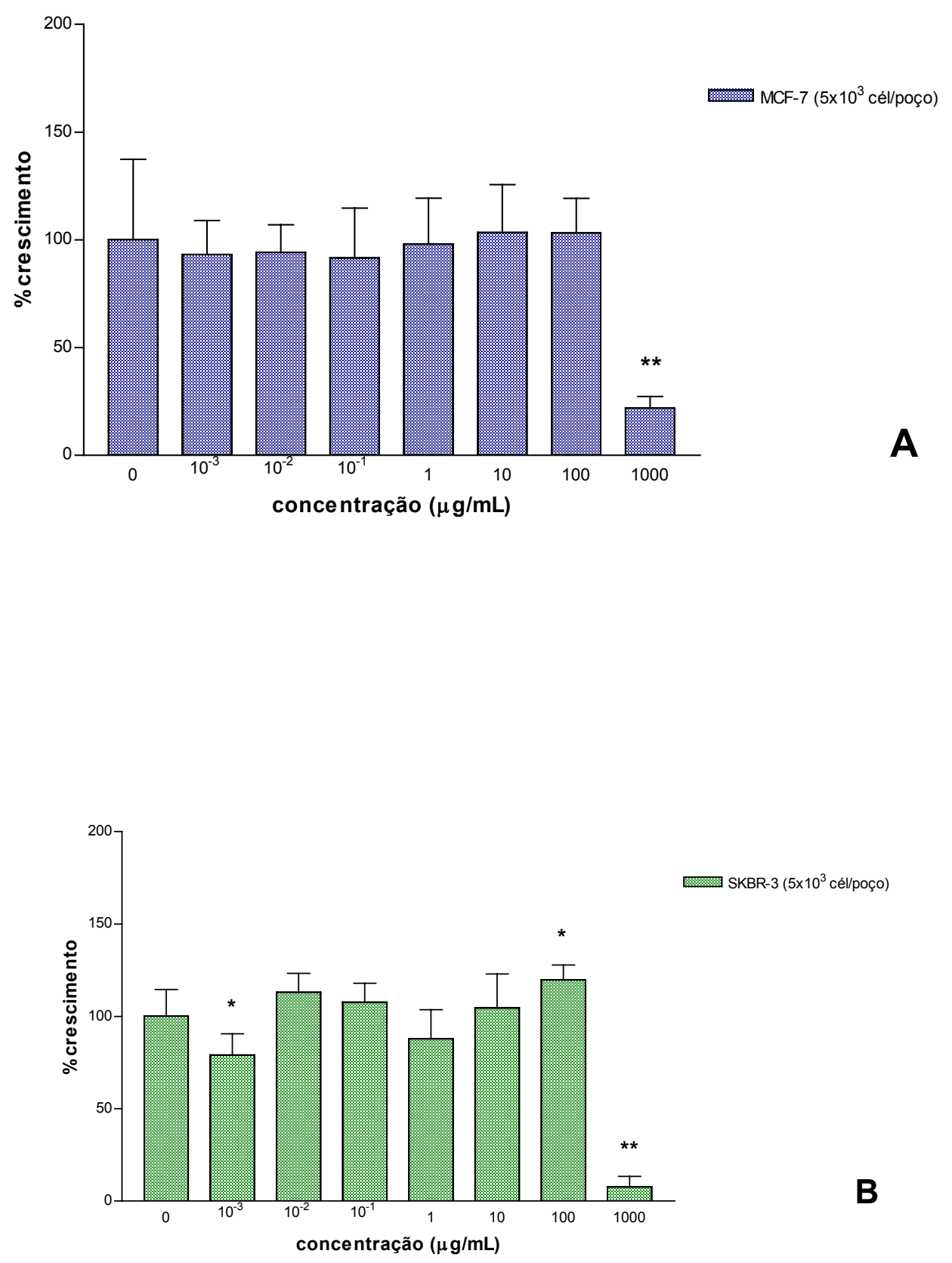

Figura 5 - Crescimento das células MCF-7 (A) e SKBR-3 (B) tratadas com extrato butanólico por 48 horas. O tratamento com $1000 \mu \mathrm{g} / \mathrm{mL}$ de extrato butanólico causou diminuição do crescimento celular nas células MCF-7 e SKBR-3, estatisticamente significante. ANOVA $\mathrm{P}<0,0001 ;{ }^{*} \mathrm{P}<0,05 ;{ }^{* *} \mathrm{P}<0,01$ (teste de Dunnett). 


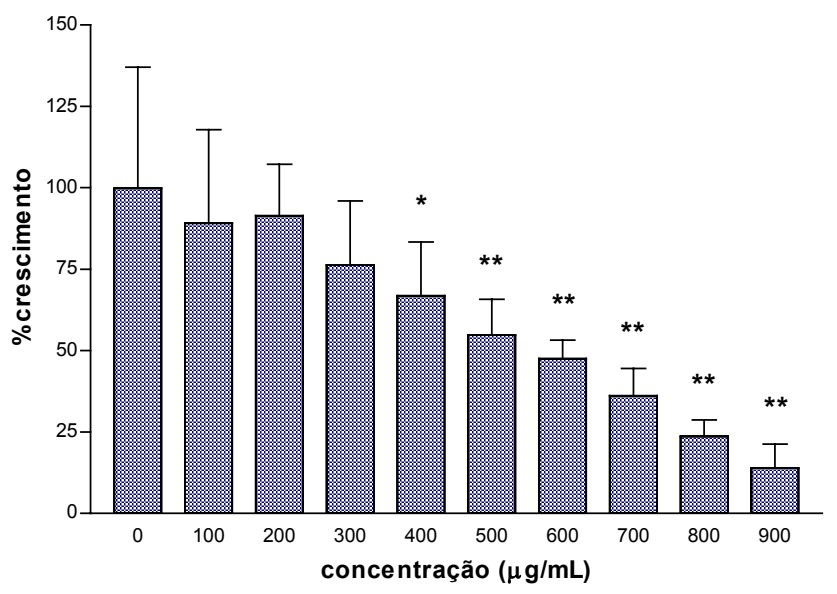

MCF-7 $\left(5 \times 10^{3}\right.$ cél/poço)

A

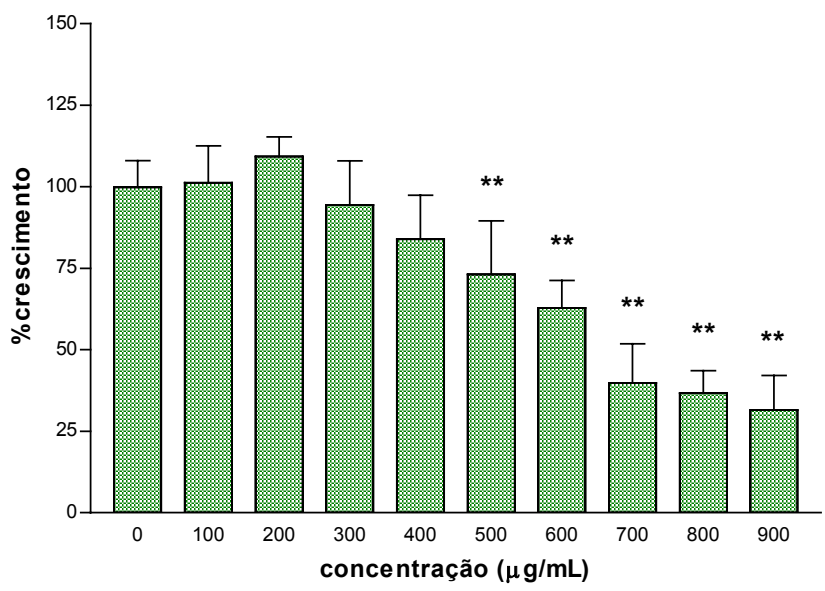

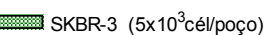

Figura 6 - Crescimento das células MCF-7(A) e SKBR-3 (B) após tratamento com extrato butanólico. As células foram tratadas com extrato butanólico $(100 \mu \mathrm{g}-900 \mu \mathrm{g} / \mathrm{ml})$ durante 48 horas. A linhagem MCF-7 apresentou redução significativa do crescimento a partir de $400 \mu \mathrm{g} / \mathrm{mL}$ do extrato. Na linhagem SKBR-3, a redução é alcançada com $500 \mu \mathrm{g} / \mathrm{mL}$ de extrato butanólico. O teste estatístico ANOVA para cada um dos gráficos é significante $(P<0,0001) ;{ }^{*} P<0,05 ;{ }^{*} P<0,01$ (pós-teste de Dunnett). 

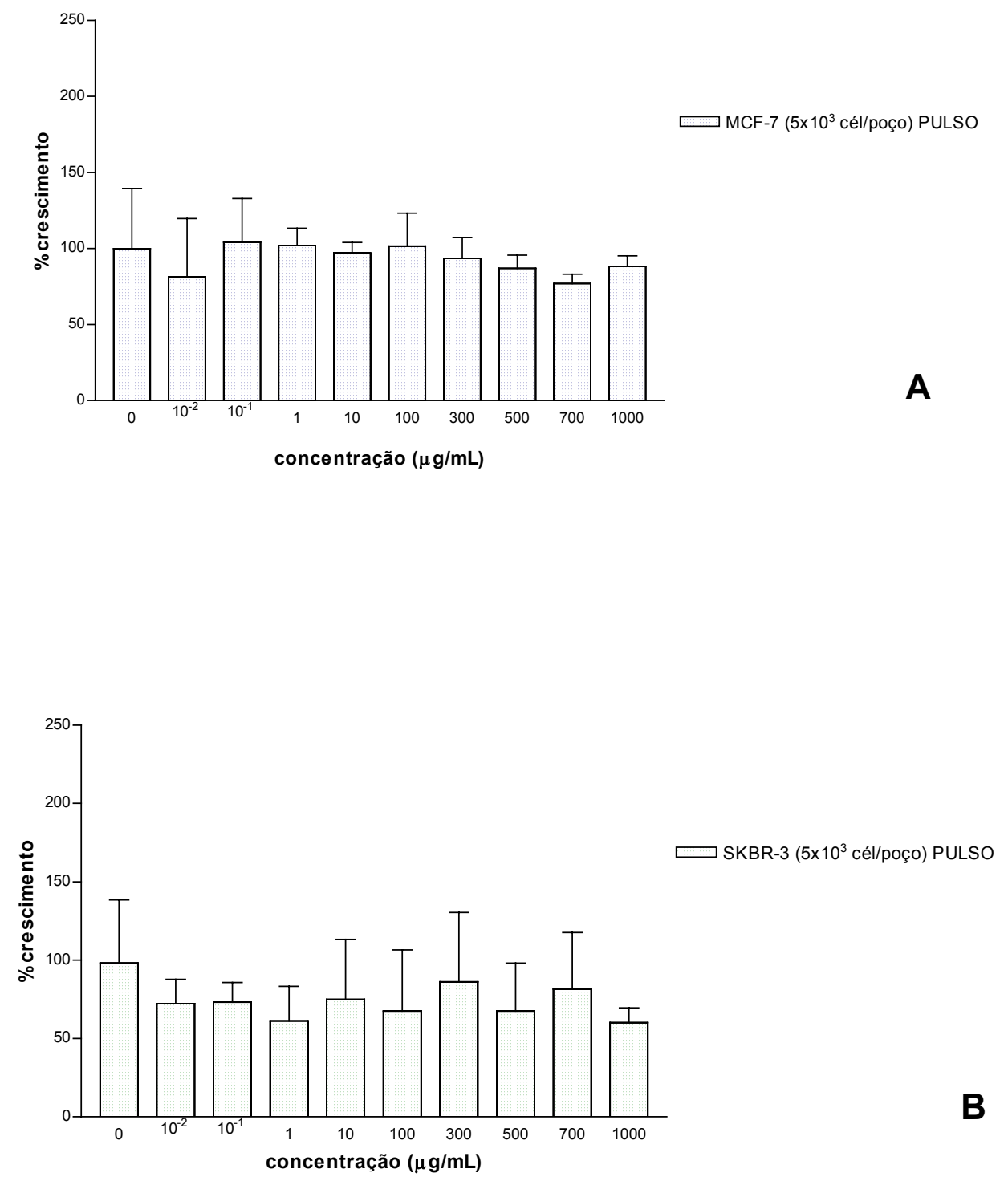

Figura 7 - Crescimento das células MCF-7 (A) e SKBR-3 (B) após tratamento tipo pulso com extrato etanólico. Não houve diferença estatística com o tratamento nas linhagens MCF-7 e SKBR-3. 


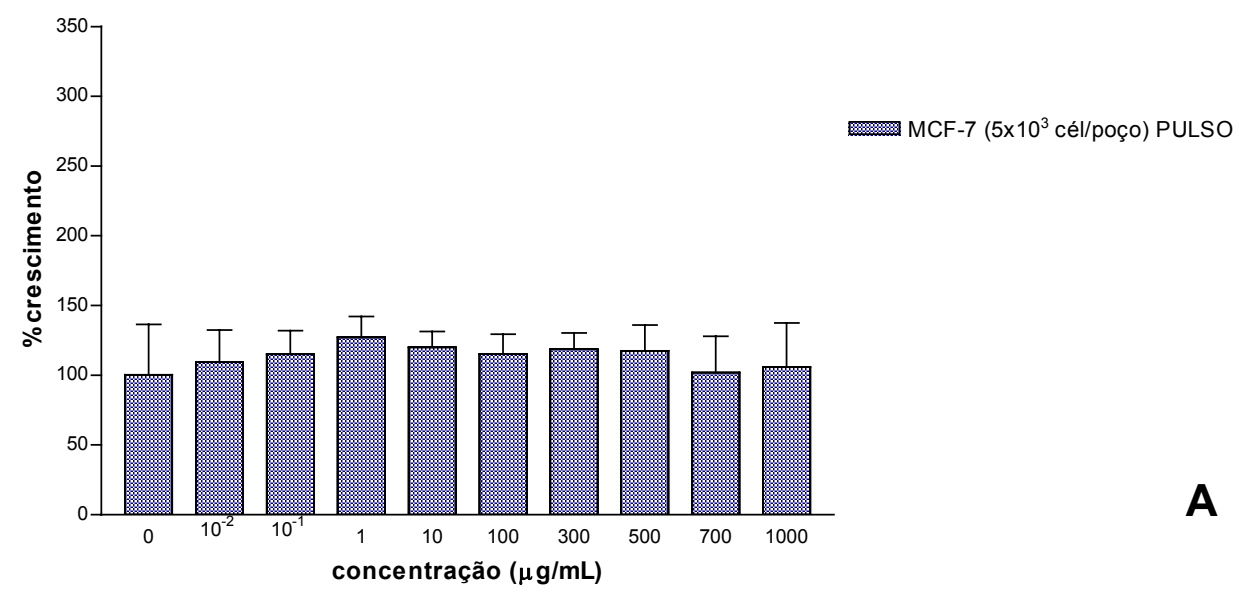

A

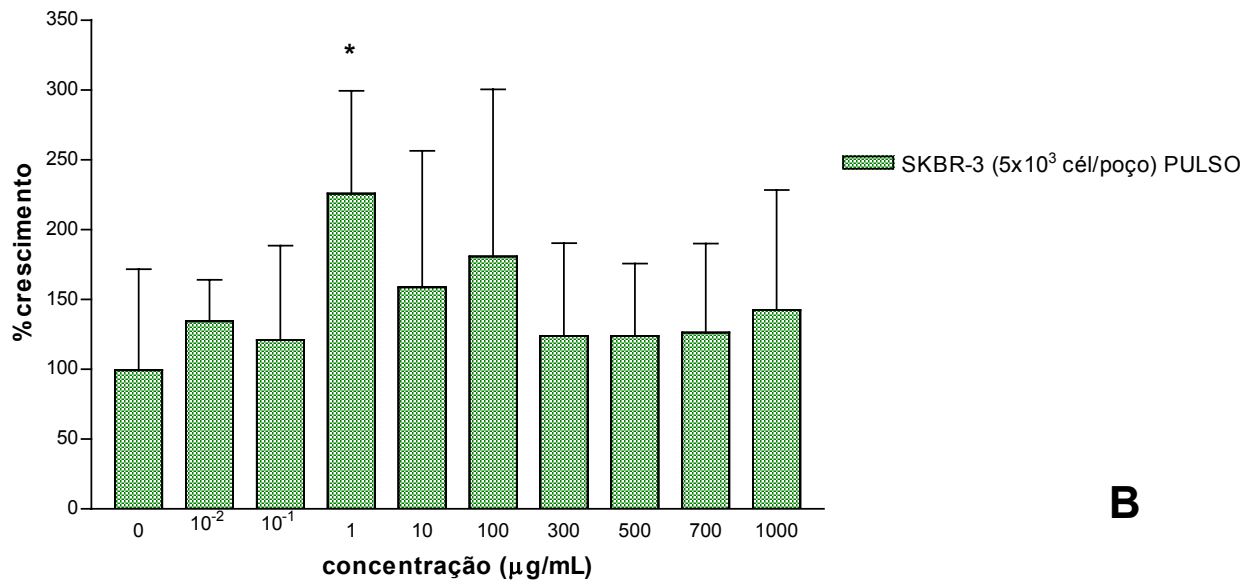

Figura 8 - Crescimento das células MCF-7 (A) e SKBR-3 (B) após tratamento tipo pulso com extrato butanólico. $O$ tratamento nas células MCF-7 não causou efeitos estatisticamente significantes sobre o crescimento celular. As células SKBR-3 apresentaram aumento do crescimento com a concentração de $1 \mu \mathrm{g} / \mathrm{mL}$. ${ }^{*} \mathrm{P}<0,05$ (pós-teste de Dunnett). 


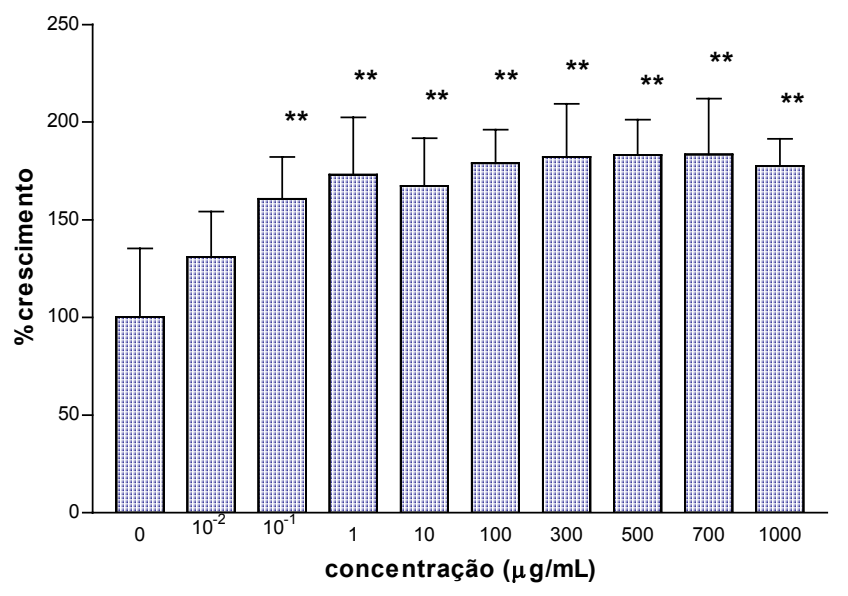

\#掣 MCF-7 ( $5 \times 10^{3}$ cél/poço) PULSO

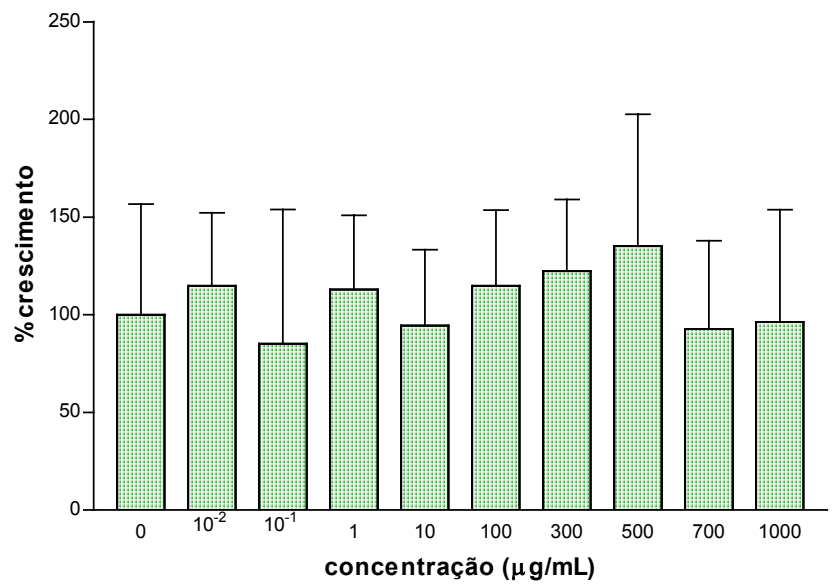

SKBR-3 $\left(5 \times 10^{3}\right.$ cél/poço) PULSO

Figura 9 - Crescimento das células MCF-7 (A) e SKBR-3 9 (B) após tratamento tipo pulso com extrato aquoso. $O$ tratamento na linhagem MCF-7 produziu um efeito estimulatório sobre o crescimento das células (ANOVA $\mathrm{P}<0,0001$ ). Na linhagem SKBR-3 não se observa diferença estatística. ${ }^{* *} \mathrm{P}<0,01$ (pós-teste de Dunnett). 


\subsection{Detecção de morte celular pelo método da laranja de acridina e brometo de etídio}

Para verificar a possibilidade de morte celular, a técnica da laranja de acridina/brometo de etídio foi realizada. A laranja de acridina é um corante vital, corando as células vivas em verde. Células mortas são coradas em vermelho pelo brometo de etídio, que só penetra em células com alteração de permeabilidade celular (SPECTOR, 1998).

$\mathrm{Na}$ figura 10, pode-se observar o aumento progressivo de morte celular de acordo com a concentração do extrato butanólico, de maneira dose dependente. As células foram tratadas por 48 horas com diluições de $500 \mu \mathrm{g} / \mathrm{mL}, 750 \mu \mathrm{g} / \mathrm{mL}$ e $1000 \mu / \mathrm{mL}$ de extrato butanólico. A células que receberam somente meio de cultura (controle), mostraram uma quantidade mínima de células mortas, refletindo um índice basal de morte celular.

Para determinar se ocorre morte celular logo no início do tratamento, foi realizado outro ensaio com as células MCF-7 nos tempos de 1, 4, 24 e 48 horas após a adição do extrato butanólico. Pode-se observar na tabela 5, a ocorrência de morte celular já na primeira hora, a partir da concentração de $300 \mu \mathrm{g} / \mathrm{mL}$ de extrato butanólico. As células com tratamentos de 300 e $500 \mu \mathrm{g} / \mathrm{mL}$ apresentaram vários grupos de células mortas, adjacentes umas às outras (Figuras 11B e 11C). Estes grupos de células mortas foram observadas no tratamento de $300 \mu \mathrm{g} / \mathrm{mL}$ no tempo de 1, 4 e 24 horas, desaparecendo no tempo de 48 horas. 
A concentração de $500 \mu \mathrm{g} / \mathrm{mL}$ mostra morte celular em grupos de células no tempo de 1hora, que diminui progressivamente nos tempos de 4, 24 e 48 horas, ficando evidente entretanto, restos celulares e alteração de morfologia celular.

A diminuição de células mortas se repetiu no tratamento com $1000 \mu \mathrm{g} / \mathrm{mL}$, com o aumento concomitante de restos celulares, alterações de morfologia celular e redução da densidade celular (Tabela 5 e figuras 12C, 12E e 12F). É interessante ressaltar que o período de 48 horas aparentemente apresentou ter mais células vivas em relação a 24 horas, porém notou-se que estas células estavam com o aspecto completamente diferente do controle, apresentando inclusive vacuolização citoplasmática (Figura 12E).

O tratamento com $100 \mu \mathrm{g} / \mathrm{mL}$ provocou morte celular mais tardiamente, nos tempos de 24 e 48 horas, semelhante ao observado com o tratamento de $300 \mu \mathrm{g} / \mathrm{mL}$ (figura 12B).

O tratamento com $10 \mu \mathrm{g} / \mathrm{mL}$ aparentemente não interferiu no crescimento e morte celular das células tratadas em todos os tempos analisados. Seu aspecto morfológico foi semelhante às células do controle. 

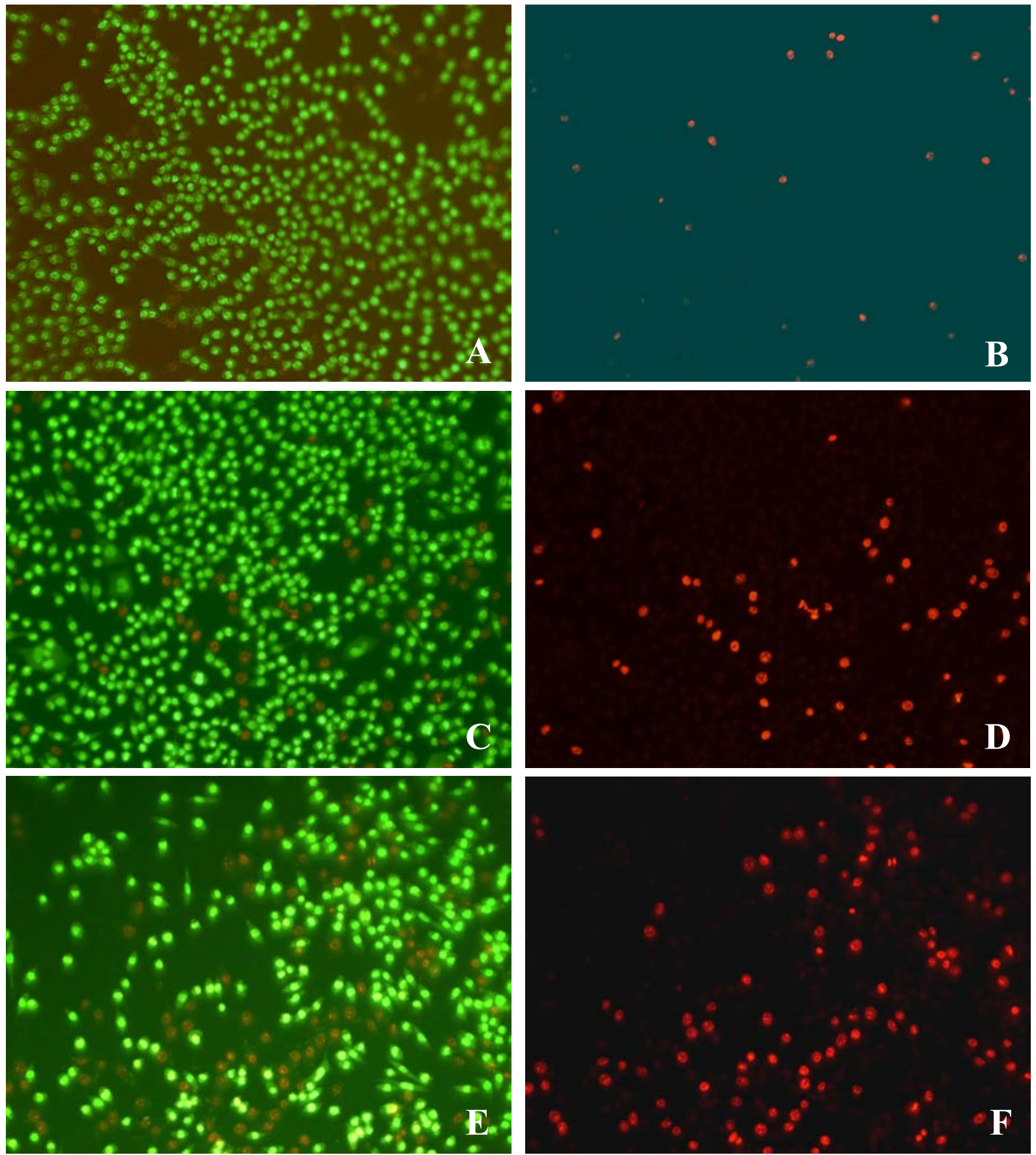

Figura 10 - Detecção de morte celular por coloração com laranja de acridina/brometo de etídio, visualizada com diferentes filtros para fluorescência. As figuras (A), (C) e (E) referem-se ao tratamento das células MCF-7 com $500 \mu \mathrm{g} / \mathrm{ml}, 750 \mu \mathrm{g} / \mathrm{ml}$ e $1 \mathrm{mg} / \mathrm{ml}$, respectivamente, observados com filtro de excitação para FITC-TEXAS RED. As figuras da direita são correspondentes às figuras do lado esquerdo vistos com filtro de excitação 528-553nm e mostram células mortas. Objetiva 4X. 

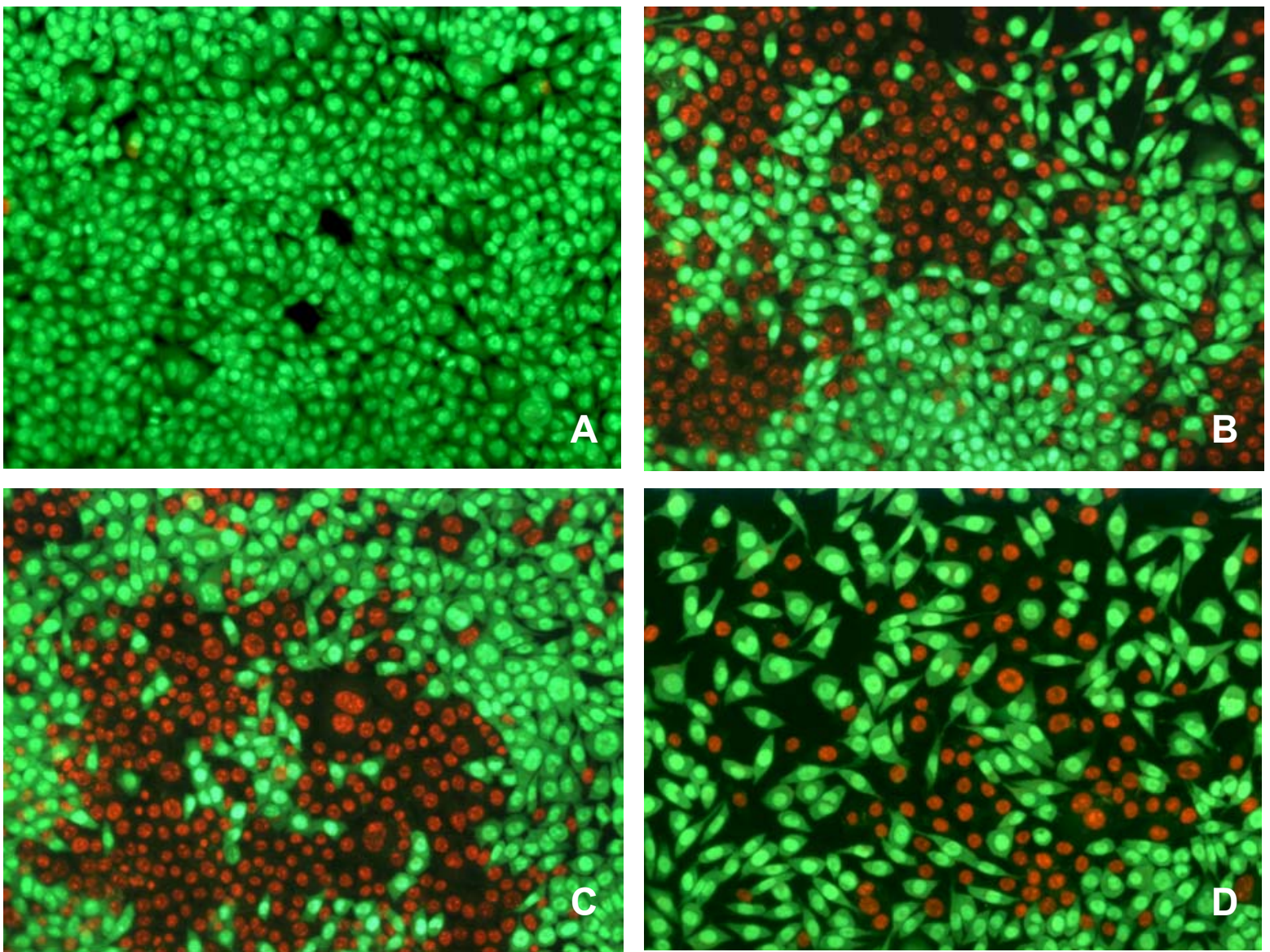

Figura 11 - Detecção de morte celular por coloração com laranja de acridina/brometo de etídio. As células MCF-7 foram tratadas com extrato butanólico com diferentes contrações do extrato butanólico por 1 hora. (A) controle. (B) $300 \mu \mathrm{g} / \mathrm{ml} \mathrm{e} \mathrm{(C)} 500 \mu \mathrm{g} / \mathrm{ml}$ apresentando extensiva morte celular, em blocos de células. (D) $O$ tratamento das células com $1000 \mu \mathrm{g} / \mathrm{ml}$ de extrato butanólico causou diminuição da densidade celular. Objetiva $10 \mathrm{X}$. 

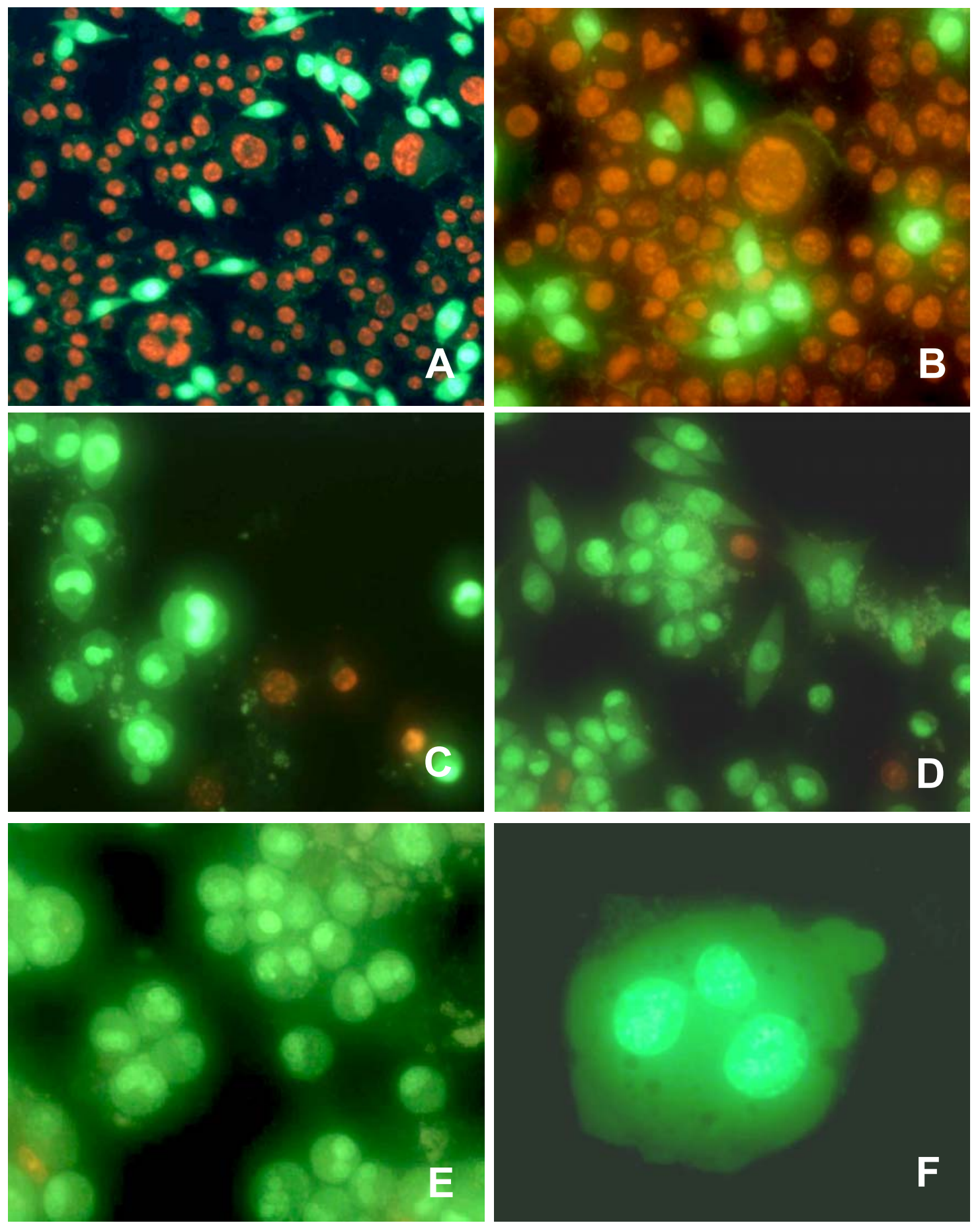

Figura 12 - Detecção de morte celular em células MCF-7 por coloração com laranja de acridina/brometo de etídio. (A) Tratamento das células com $300 \mu \mathrm{g} / \mathrm{ml}$ do extrato butanólico causou extensiva morte celular após 4 de tratamento. Após 24 horas de tratamento a concentração de $100 \mu \mathrm{g} / \mathrm{ml}$ de extrato butanólico causou morte celular (B), e a concentração de $1000 \mu \mathrm{g} / \mathrm{ml}$, drástica diminuição do número de células, com alterações morfológicas (C). Em (D), nota-se debris celulares com o tratamento de $500 \mu \mathrm{g} / \mathrm{ml}$ e células com alteração de morfologia. Em (E) e (F) é mostrado as células tratadas com $1000 \mu \mathrm{g} / \mathrm{ml}$ do extrato butanólico após 48 horas de tratamento. As células formam grumos $(E)$ e apresentam vacuolização citoplasmática (F). Fluorescência. Objetiva 10X: (A); Objetiva 20X: (B), (C), (D), (E) e (F). 
Tabela 5 - Evolução de morte celular, de acordo com o tempo de tratamento com diferentes concentrações do extrato butanólico, avaliadas pelo método da laranja de acridina/brometo de etídio.

\begin{tabular}{|c|c|c|c|c|}
\hline \multirow[b]{2}{*}{$\begin{array}{l}\text { Concentração } \\
(\mu \mathrm{g} / \mathrm{mL})\end{array}$} & \multicolumn{4}{|c|}{ Tempo de tratamento } \\
\hline & 1 hora & 4 horas & 24 horas & 48 horas \\
\hline 10 & SDE & SDE & SDE & SDE \\
\hline 100 & SDE & SDE & $\begin{array}{l}\text { Morte celular +++ } \\
\text { em grupos de } \\
\text { células }\end{array}$ & $\begin{array}{l}\text { Morte celular +++ } \\
\text { em grupos de } \\
\text { células }\end{array}$ \\
\hline 300 & $\begin{array}{l}\text { Morte celular } \\
+++ \text { em grupos } \\
\text { de células }\end{array}$ & $\begin{array}{l}\text { Morte celular } \\
+++ \text { em grupos } \\
\text { de células }\end{array}$ & $\begin{array}{l}\text { Morte celular +++ } \\
\text { em grupos de } \\
\text { células, restos } \\
\text { celulares }\end{array}$ & $\begin{array}{l}\text { Morte celular - } \\
\text { espaços }\end{array}$ \\
\hline 500 & $\begin{array}{l}\text { Morte celular } \\
+++ \text { em grupos } \\
\text { de células }\end{array}$ & $\begin{array}{l}\text { Morte celular } \\
++, \text { espaços }\end{array}$ & $\begin{array}{l}\text { Morte celular + } \\
\text { em grupos de } \\
\text { células, espaços, } \\
\text { restos celulares }\end{array}$ & $\begin{array}{l}\text { Morte celular -, } \\
\text { espaços, muitos } \\
\text { restos celulares, } \\
\text { muitas células } \\
\text { arredondadas }\end{array}$ \\
\hline 1000 & $\begin{array}{l}\text { Morte celular } \\
++, \text { espaços }\end{array}$ & $\begin{array}{l}\text { Morte celular - } \\
\text {, espaços }\end{array}$ & $\begin{array}{l}\text { Muitos restos } \\
\text { celulares, células } \\
\text { com alterações } \\
\text { em morfologia, } \\
\text { células mortas + }\end{array}$ & $\begin{array}{l}\text { Morte celular -, } \\
\text { grupos de células } \\
\text { vivas com alteração } \\
\text { morfológica, restos } \\
\text { celulares, } \\
\text { vacuolização } \\
\text { citoplasmática }\end{array}$ \\
\hline
\end{tabular}

SDE: sem diferença evidente em relação ao controle

Morte celular +++: muitas células mortas

Morte celular ++: quantidade intermediária de células mortas

Morte celular +: poucas células mortas

Morte celular -: pouquíssimas células mortas 


\subsection{Crescimento celular com tratamentos de 24 e 48 horas}

O ensaio de citotoxicidade foi repetido no tempo de 24 horas, a fim de se comparar a taxa de crescimento após 24 e 48 horas de tratamento. Como pode ser observado pelo gráfico (figura13), em ambos os tratamentos houve redução do crescimento das células tratadas, de maneira dose dependente. Embora tenha ocorrido redução de crescimento nas células tratadas em relação ao controle, ocorreu um aumento do crescimento celular de 24 para 48 horas, ou seja, apesar de ter ocorrido morte celular, as células provavelmente continuaram em proliferação.

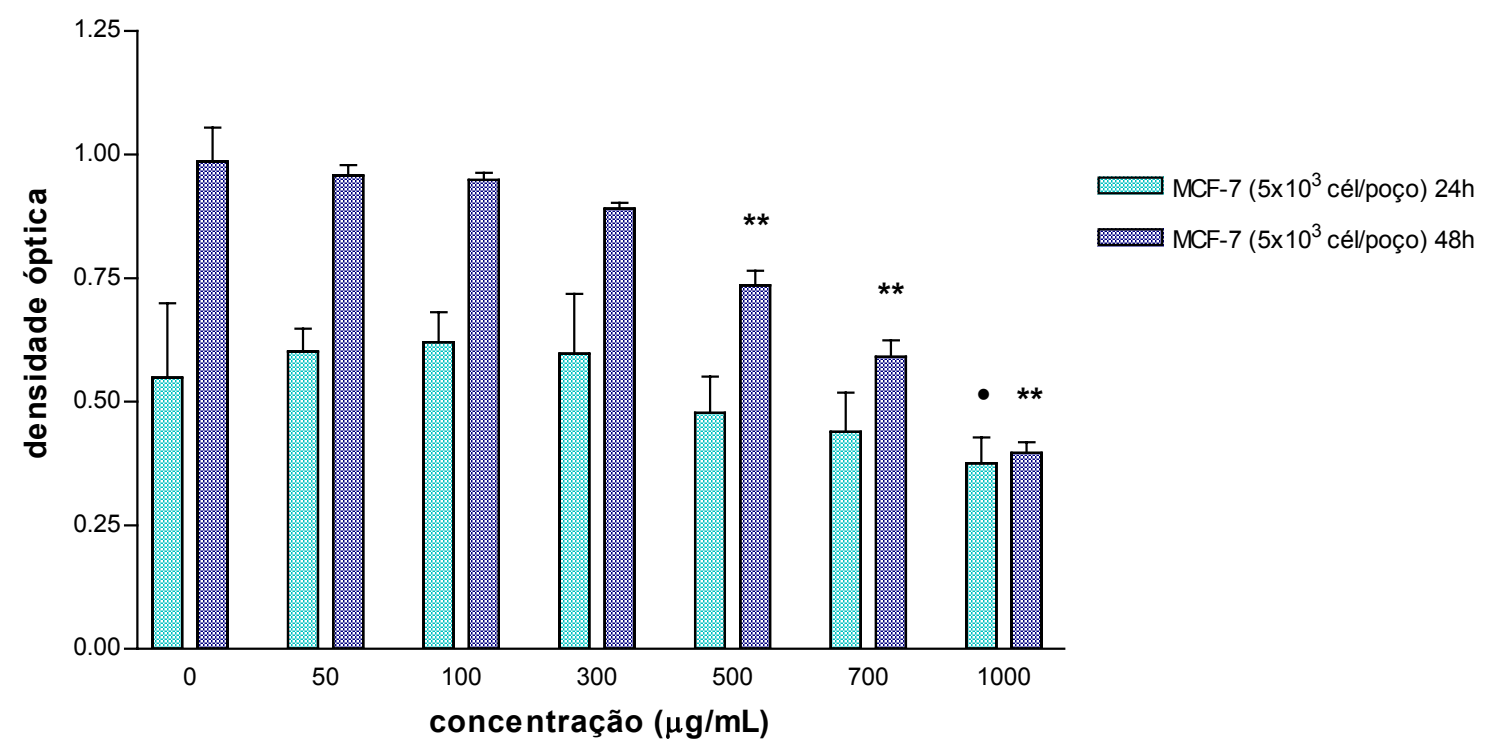

Figura 13 - Densidade óptica de células MCF-7 tratadas com diversas concentrações de extrato butanólico por 24 ou 48horas. Observa-se um aumento da densidade óptica do tempo de 24 horas para o tempo de 48 horas, um indicativo da ocorrência de proliferação celular. Existe diminuição significativa do crescimento celular quando se consideram os tratamentos nos tempos individualizados, em relação aos respectivos controles. ANOVA, $\mathrm{P}=0,0007$ para otempo de $24 \mathrm{~h}$ e $P<0,0001$ para o tempo de 48h. Pós teste Dunnett: $\bullet P<0,05 ;{ }^{* *} P<0,01$. 


\subsection{Verificação de células em proliferação por meio da marcação de núcleos que incorporam bromodeoxiuridina (BrdU)}

Com o intuito de se verificar a possibilidade de proliferação celular nas células tratadas, foi realizado a quantificação de núcleos positivos para bromodeoxiuridina (BrdU). O núcleo das células positivas para a BrdU se cora em marrom (células na fase de síntese do ciclo celular que incorporam a BrdU), enquanto as células que não estão na fase $S$ do ciclo permanecem com o núcleo claro (Figura 14A). As células foram contadas em vários campos e a porcentagem de núcleos marcados positivamente para a BrdU está expresso na tabela 6.

O índice proliferativo das células não tratadas e tratadas com diversas diluições de extrato butanólico por 48 horas foi semelhante, por volta de $50 \%$. Apesar do índice de células em proliferação ter sido semelhante nas culturas tratadas e não tratadas, a densidade celular observada nos poços tratados com o extrato butanólico diminuiu de acordo com o aumento da concentração do extrato (Figura 15). Isto indica que as células continuaram a se proliferar, e a redução do crescimento celular foi decorrente de morte celular, e não da inibição de proliferação (condizente com o método da laranja de acridina/brometo de etídio).

$\mathrm{Na}$ observação da morfologia celular pôde-se notar que células que receberam o extrato butanólico da P.paniculata apresentaram-se mais contraídas em relação às células que não foram tratadas com o extrato (Figura 16). Foram observadas muitas células em formato arredondado, que tanto poderiam ser células em divisão celular, quanto em processo de morte celular (Figuras 16C e 16D). 
Tabela 6 - Porcentagem de núcleos marcados positivamente para BrdU nas linhagens MCF-7 e SKBR-3 tratadas por 48 horas com extrato butanólico.

\begin{tabular}{ccccc}
\hline & \multicolumn{4}{c}{ Tratamento $(\mu \mathrm{g} / \mathrm{mL})$} \\
\cline { 2 - 5 } $\begin{array}{c}\text { Linhagem de } \\
\text { célula }\end{array}$ & $\begin{array}{c}\text { Controle } \\
\mathbf{( \% )}\end{array}$ & $\mathbf{5 0 0}$ & $\mathbf{7 5 0}$ & $\mathbf{1 0 0 0}$ \\
& $\mathbf{( \% )}$ & $\mathbf{( \% )}$ & $\mathbf{( \% )}$ \\
\hline MCF-7 & 55,9 & 53,89 & 52,91 & 48 \\
SKBR-3 & 47,51 & 51,53 & 53,88 & 46,9 \\
\hline
\end{tabular}
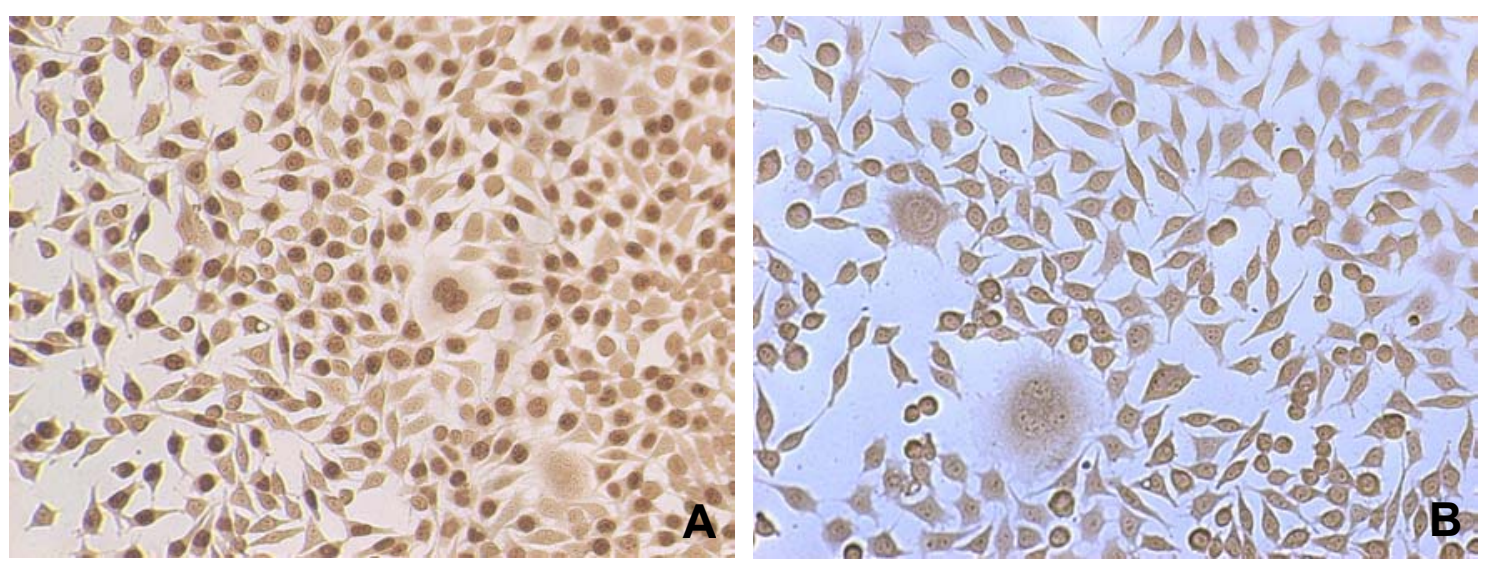

Figura 14 - Marcação da BrdU por imunocitoquímica em células MCF-7. (A) Os núcleos que incorporaram a bromodeoxiuridina são vistos em marrom. Células que não estão na fase de síntese de DNA apresentam núcleos claros. (B) Controle negativo. Objetiva 10X.
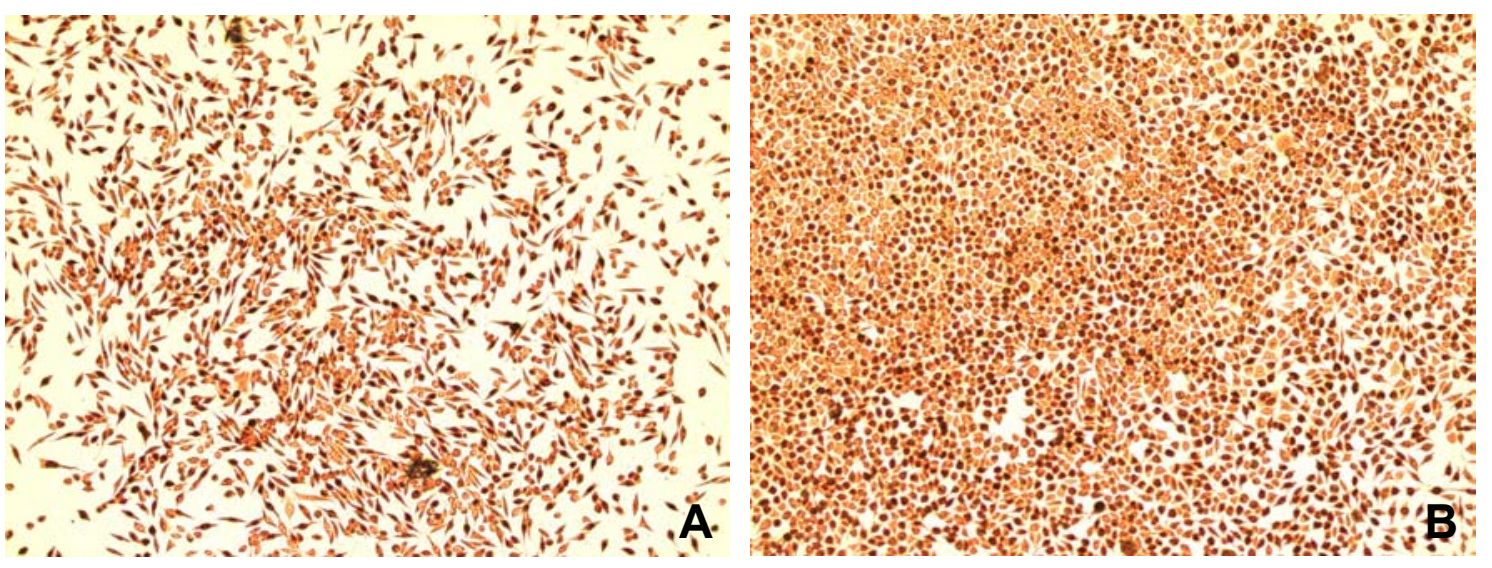

Figura 15 - Marcação para BrdU. (A) Células MCF-7 tratadas com $1000 \mu \mathrm{g} / \mathrm{mL}$ de extrato butanólico por 48 horas. (B) Células MCF-7 não tratadas com extrato butanólico. Notar a densidade de células. Objetiva 4X. 


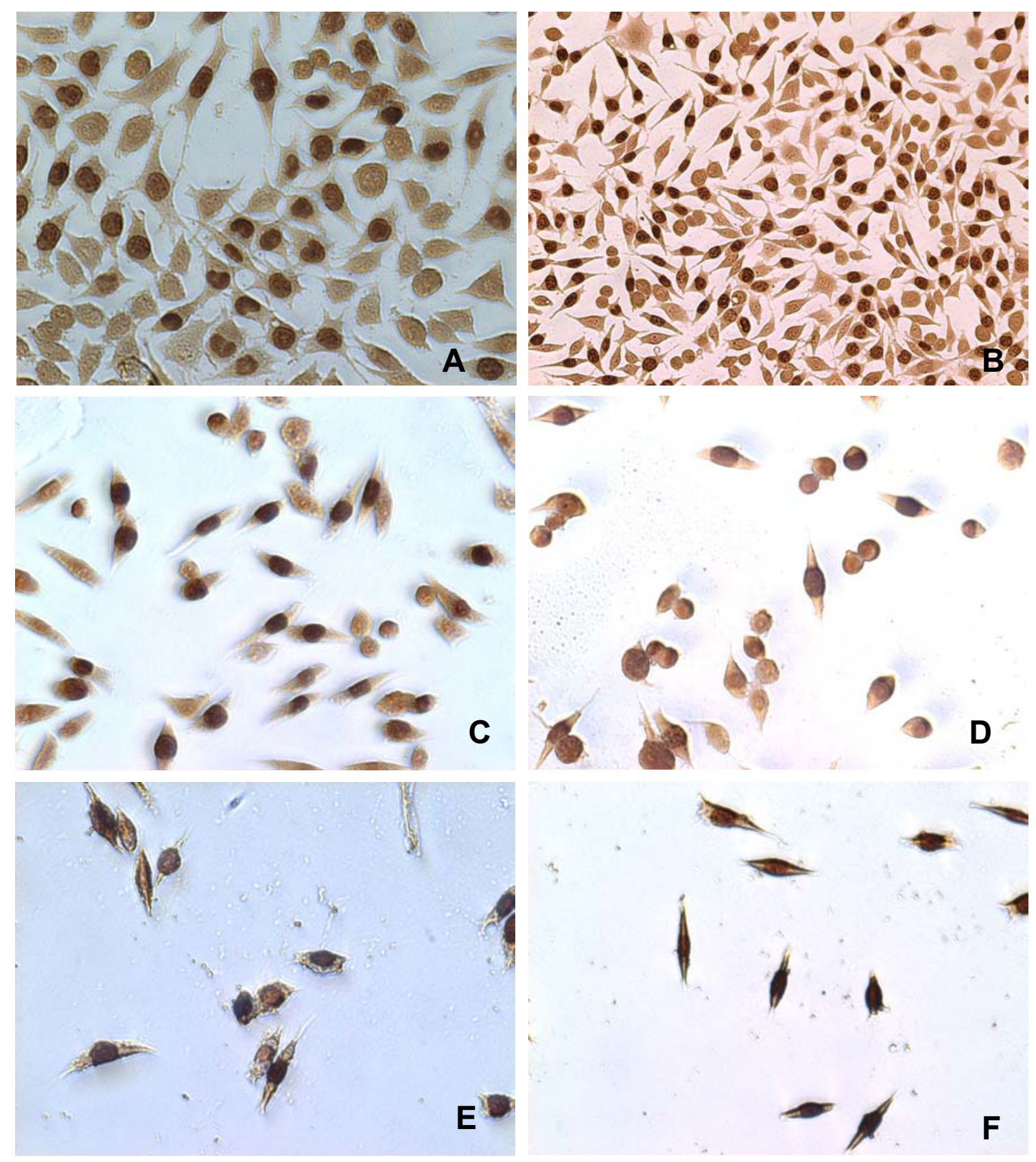

Figura 16 - Imunocitoquímica para BrdU. Células controle: (A) SKBR-3 e (B) MCF-7. As células SKBR-3 (C e E) e MCF-7 (D e F) foram tratadas com $1000 \mu \mathrm{g} / \mathrm{mL}$ do extrato butanólico por 48 horas e mostram núcleos positivos para BrdU (em marrom). Notam-se muitas células arredondadas. $(E)$ e $(F)$ : células com formato estreitado e núcleo enegrecido estão provavelmente mortas. Objetiva 10X: (A), (B), (C), (D), (E) e (F). 


\subsection{Microscopia Eletrônica}

As células MCF-7 que não foram tratadas com o extrato butanólico apresentaram um pequeno desarranjo citoplasmático (presença de corpúsculos residuais), mitocôndrias aparentemente hígidas, carioteca e cromatina bem preservadas (Figura 17).

As células MCF-7 tratadas com $500 \mu \mathrm{g} / \mathrm{mL}$ do extrato butanólico por 48 horas apresentaram citoplasma sem características vitais e ausência de organelas hígidas (figuras 18 e 19). A membrana citoplasmática das células mostrou inúmeros prolongamentos e rupturas. A cromatina apresentou-se totalmente desespiralizada (Figura 18). Pode-se depreender que existe um processo para a inviabilidade celular.

O tratamento das células MCF-7 com $1000 \mu \mathrm{g} / \mathrm{mL}$ de extrato butanólico por 48 horas mostrou profundas alterações citoplasmáticas e nucleares, incompatíveis com a viabilidade celular. Não foram observadas estruturas citoplasmáticas ou nucleares que pudessem ser individualizadas, mostrando um quadro evidente de morte celular (Figura 19). 

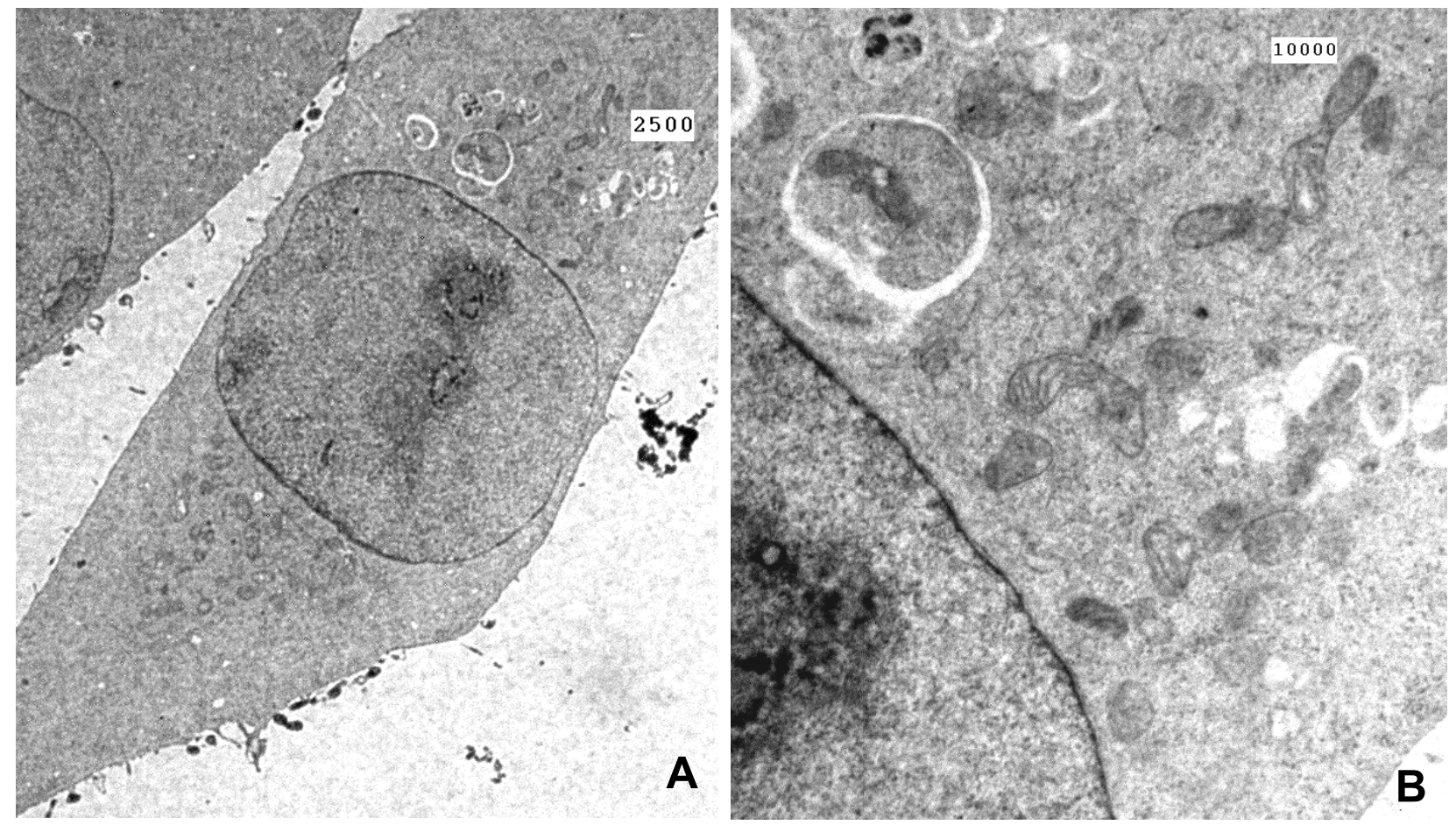

Figura 17 - Microscopia eletrônica de transmissão. A) Células MCF-7 cultivadas por 48 horas sem tratamento. Nota-se a presença de mitocôndrias e corpúsculos residuais. A carioteca e cromatina estão bem preservadas.
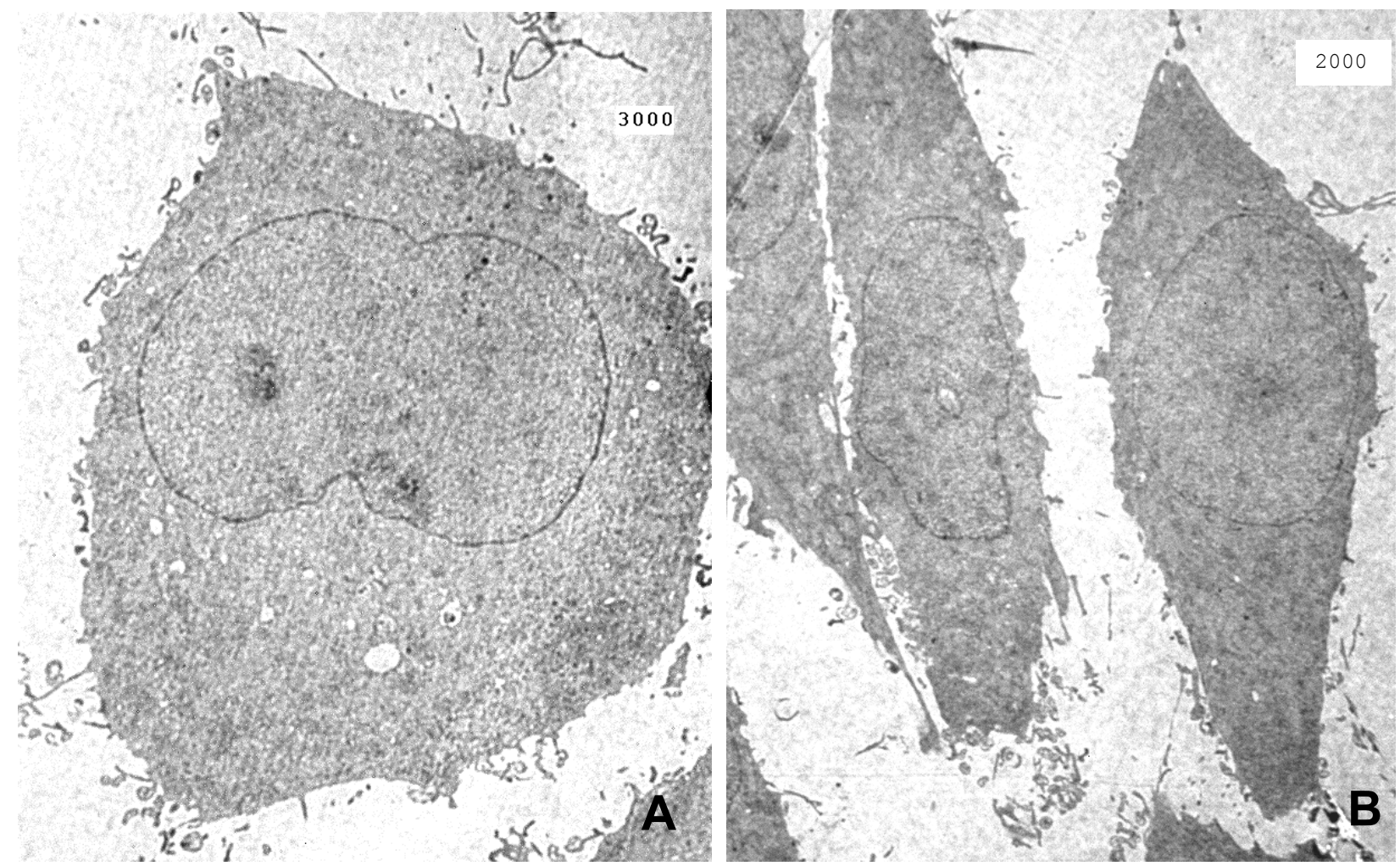

Figura 18 - Microscopia eletrônica de transmissão. (A) e (B) Células MCF-7 tratadas com $500 \mu \mathrm{g} / \mathrm{mL}$ de extrato butanólico por 48 horas. Observam-se inúmeros prolongamentos, ruptura de membrana citoplasmática e citoplasma sem características vitais. 


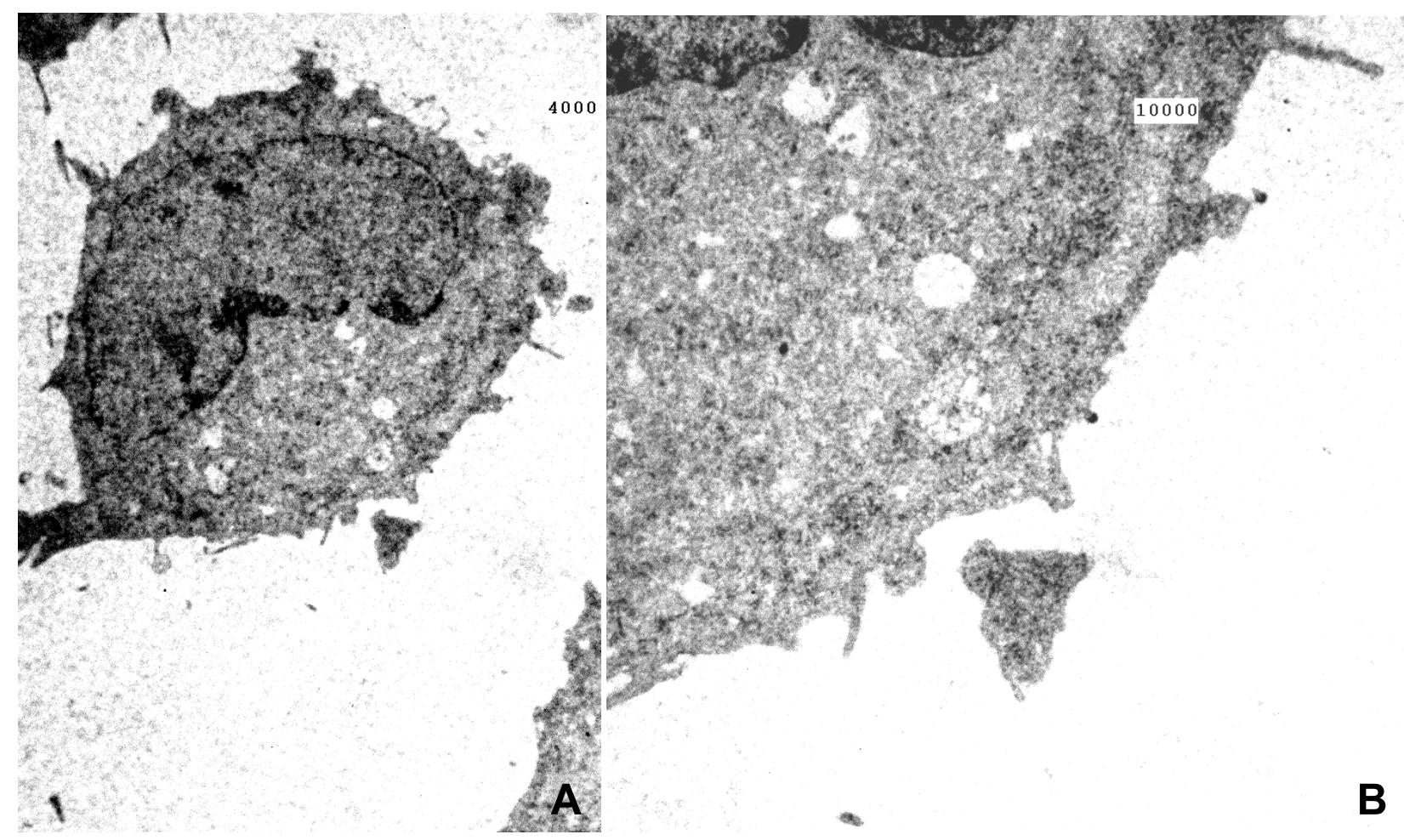

Figura 19 - Microscopia eletrônica de transmissão. (A) Células MCF-7 tratadas com $500 \mu \mathrm{g} / \mathrm{mL}$ do extrato butanólico por 48 horas, mostrando degeneração citoplasmática (B) Detalhe do citoplasma da célula mostrada em (A).
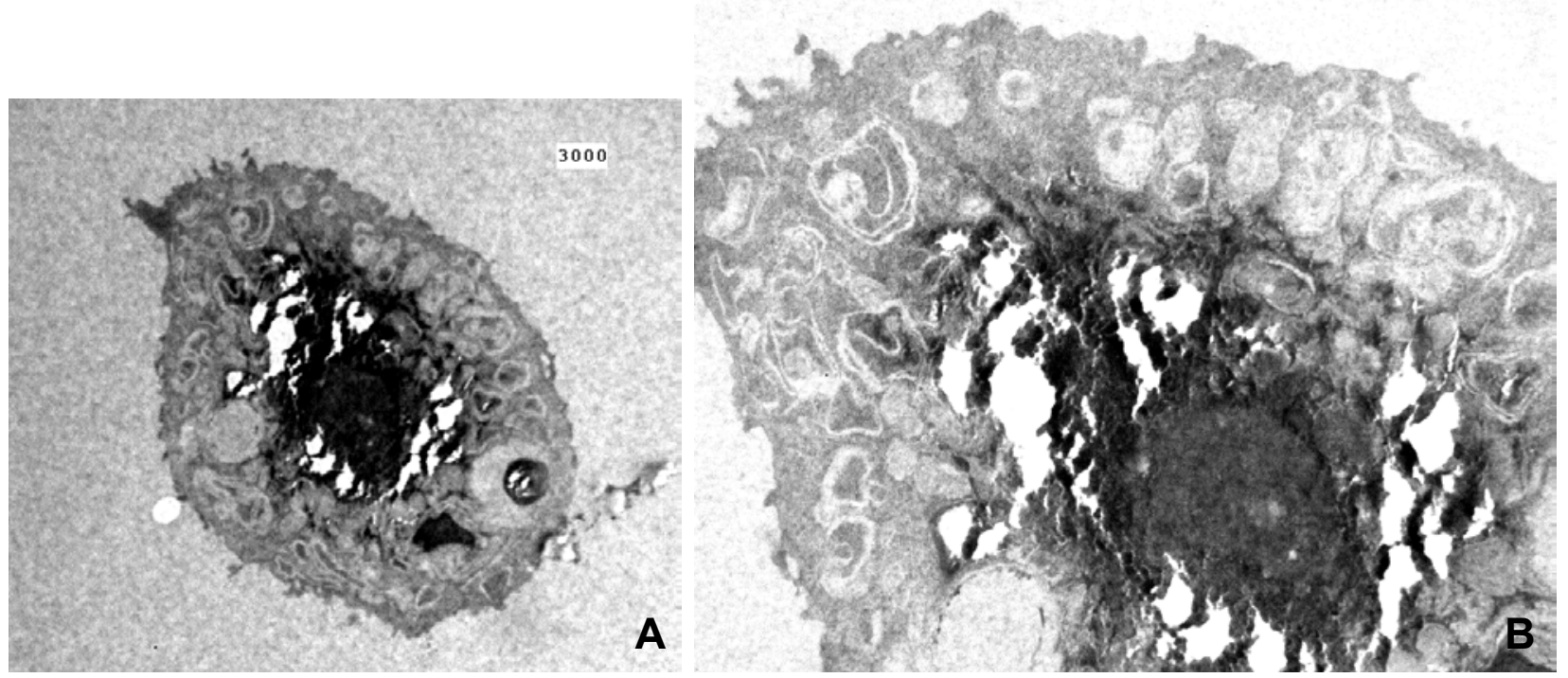

Figura 20 - Microscopia eletrônica de transmissão. (A) Célula MCF-7 tratada com $1000 \mu \mathrm{g} / \mathrm{mL}$ de extrato butanólico por 48 horas. A célula apresenta degeneração de componentes citoplasmáticos e nucleares. (B) Aumento maior da figura A. 


\section{DISCUSSÃO}

Trabalhos anteriores realizados neste laboratório utilizando a raiz pulverizada de Pfaffia paniculata como tratamento em camundongos portadores de tumor de Ehrlich (MATSUZAKI et al., 2003) e sobre a incidência de tumores hepáticos induzidos quimicamente pela dietilnitrosamina em camundongos (SILVA, 2003) demonstraram respectivamente efeitos antineoplásico contra o tumor transplantável de Ehrlich e quimiopreventivo de lesões hepatocelulares preneoplásicas. Além disso, um teste prévio realizado com linhagens de células tumorais no Laboratório de Imunologia de Tumores do Instituto de Ciências Biomédicas IV/USP sugeriu uma sensibilidade maior da linhagem tumoral de células mamárias humanas MCF-7 ao tratamento com extrato metanólico da P.paniculata. Outras linhagens utilizadas foram o melanoma humano C8161 e o fibrossarcoma murino L929, sem resultados satisfatórios.

O trabalho com plantas se mostra bastante complexo, pela variedade de compostos presentes e muitos com ações opostas. A quantidade presente na planta/extrato é muito importante, visto que uma quantidade muito pequena pode ter seus efeitos mascarados. Uma das características mais importantes da descoberta de novos compostos é o modelo químico/estrutural que pode ser posteriormente modificado para potencializar efeitos desejados ou diminuir efeitos adversos.

A avaliação do tratamento com extrato butanólico nas linhagens MCF-7 e SKBR-3 evidenciou uma redução do crescimento destas células de maneira dose dependente, com comportamento semelhante frente ao tratamento. Houve redução estatisticamente significante a partir da concentração de $400 \mu \mathrm{g} / \mathrm{mL}$ para as células 
MCF-7 e $500 \mu \mathrm{g} / \mathrm{mL}$ para as células SKBR-3. É possível que as respostas desencadeadas nas células não estejam relacionadas ao receptor de estrógeno, já que as células MCF-7 possuem o receptor de estrógeno e as células SKBR-3 não o possuem (RØNNOV-JESSEN, PETERSEN, BISSEL, 1996).

O extrato aquoso parece ter um efeito estimulatório sobre o crescimento das células MCF-7, quando expostas por curto período de tempo (1 hora). O extrato aquoso não foi estudado mais profundamente, pois não era o objetivo deste trabalho, avaliar substâncias com atividade estimulatória sobre o crescimento celular.

Os resultados obtidos com o extrato etanólico não mostraram alterações consistentes no crescimento das células tratadas, talvez pela presença de compostos com ações opostas, existentes nos extratos aquoso e butanólico.

O método da laranja de acridina/brometo de etídio pode ser utilizado para detecção do tipo de morte celular (apoptótica ou necrótica), pela análise morfológica do núcleo celular e coloração que as células adquirem, ao observar em microscópio de fluorescência. Nesta técnica, as células vivas apresentam o núcleo amareloesverdeado, enquanto as células necróticas ou em apoptose tardia se coram em vermelho. Isto ocorre porque o brometo de etídio penetra naquelas células em que o mecanismo de controle da permeabilidade celular está comprometido. As células apoptóticas apresentam os sinais característicos da apoptose (fragmentação e contração nuclear) (SPECTOR, 1998). Com o teste da laranja de acridina/brometo de etídio foi possível evidenciar extensiva morte celular do tipo necrótica após 1 hora de tratamento com as concentrações de 300 e $500 \mu \mathrm{g} / \mathrm{mL}$ do extrato butanólico, observada pela estrutura bem preservada do núcleo e alteração da permeabilidade celular. A morte por necrose é considerada um tipo de morte acidental, não 
controlada pela célula (ZIEGLER; GROSCURTH, 2004). A apoptose e necrose foi estudada por Formigli e colegas (2000), variando a intensidade do insulto provocado por Antimicina e quantidade de energia disponível em células de fibroblastos. Eles observaram que estes dois fatores são importantes na determinação do tipo de morte celular, sendo vital a disponibilidade de ATP para o processo de apoptose. Os autores consideram apoptose e necrose, dois extremos de um contínuo de formas intermediárias da morte celular.

Com o decorrer do tempo de tratamento com o extrato butanólico, verifica-se que existe uma diminuição das células mortas (coradas em vermelho), porém o espaço entre as células aumenta, indicando menor densidade celular. Além disso, o tratamento na maior concentração do extrato butanólico $(1000 \mu \mathrm{g} / \mathrm{mL})$, mostra que as células adquirem um aspecto completamente alterado, em grumos e arredondadas, apresentando inclusive, algumas células com características apoptóticas. Portanto, parece haver morte celular inicial por necrose, e mais tardiamente por apoptose.

É interessante observar que a maioria das células mortas está adjacente uma à outra, formando blocos de células. Isto demonstra uma sensibilidade maior destas células ao tratamento. É possível que sejam subclones com uma sensibilidade maior, já que em um tumor existe heterogeneidade celular. As células MCF-7 já foram descritas como tendo variantes da mesma linhagem. Em um estudo com células MCF-7 provenientes de diferentes laboratórios, foram observadas diferentes respostas ao tratamento indutor de apoptose com fator de necrose tumoral $\alpha$ (TNFa). Algumas foram resistentes ao tratamento e outras suscetíveis, sugerindo diferenças na expressão de TNFR (receptor para TNF- $\alpha$ ), geração de ceramidas, expressão diferencial das proteínas da família Bcl-2 (envolvidas na inibição de 
apoptose), e ativação de proteases (BUROW et al., 1998). Outro estudo mostrou um padrão diferenciado da formação de ladder (padrão de fragmentação de DNA de células apoptóticas dectado por meio da corrida dos fragmentos de DNA em gel de agarose) em células MCF-7, também provenientes de laboratórios distintos, induzidas a sofrer apoptose com doxorrubicina (GOOCH; YEE, 1999).

A diminuição do crescimento provocada pelo tratamento com extrato butanólico pode ser atribuída à ocorrência de extensiva morte celular, visto que a imunomarcação da BrdU demonstrou a existência de células em fase S (síntese) do ciclo celular, ou seja, sintetizando DNA. Outro fato é o aumento da densidade óptica quando se compara o tempo de 48 horas com o tempo de 24 horas com o mesmo número inicial de células plaqueadas.

Então, o que está ocorrendo é provavelmente morte celular concomitante à entrada de células viáveis no ciclo celular. Um estudo do ciclo celular de células tratadas com o extrato butanólico seria interessante, pois poderia sugerir parada em uma das fases do ciclo. Por exemplo, as células podem estar parando na fase $\mathrm{M}$ (mitose), ou seja, entram no ciclo celular, porém não conseguem finalizar a mitose. Isto poderia explicar em parte, a incidência maior do número de células com aneuploidias observada pela microscopia eletrônica.

A catástrofe mitótica é um tipo de morte celular que ocorre durante a mitose. A morte por catástrofe mitótica é uma forma de prevenir a ocorrência de aneuploidias, de ocorrência comum em células neoplásicas (CASTEDO et al., 2004a). A supressão deste mecanismo de morte celular pode acarretar o aumento de células aneuplóides. Este tipo de morte celular é independente do p-53, envolvida na supressão tumoral, e apresenta alguns marcadores de apoptose, como a ativação da caspase 2 e 3, e liberação de citocromo c (CASTEDO et al., 2004b). 
Apesar das células MCF-7 apresentarem algumas células aneuplóides, a avaliação das células tratadas com $500 \mu \mathrm{g} / \mathrm{mL}$ do extrato butanólico pela microscopia eletrônica mostrou um número maior de células com núcleo diplóide.

Por fim, a microscopia eletrônica revela alterações profundas no citoplasma e núcleo celular, com comprometimento das organelas e estrutura nuclear, no tratamento de maior concentração, mostrando inviabilidade celular e compatíveis com apoptose. Pode-se deduzir que aquelas células observadas com o teste de laranja de acridina/brometo de etídio estão com comprometimento da viabilidade celular. O prolongamento do tempo de tratamento poderia responder se as células com alterações morfológicas conseguem manter o potencial clonogênico e dar continuidade à expansão celular, importante para a manutenção do câncer.

A ação citotóxica do extrato butanólico pode ser, em parte, produzida pelo ácido pfáfico e $\beta$-sitosterol contidos neste extrato, os quais apresentam atividades antitumorais. O ácido pfáfico, produto hidrolítico dos pfafosídeos, tem ação inibitória sobre o crescimento de melanoma B-16 in vitro (NISHIMOTO et al., 1984). O $\beta$ sitosterol induz apoptose em células de adenocarcinoma mamário humano MDAMB-231 (AWAD; ROY; FINK, 2003) e em células de carcinoma de cólon HT-116 ( $\mathrm{CHOI}$ et al, 2003), e está envolvido na ativação de caspases. Nas células HT-116 há também diminuição da expressão da proteína anti-apoptótica Bcl-2 e aumento da proteína pró-apoptótica Bax, e liberação de citocromo c da mitocôndria no citosol, todas envolvidas na cascata apoptótica. Entretanto, outro estudo mostra que o tratamento in vitro de células MCF-7 estimula o crescimento, possivelmente estando relacionado com o receptor de estrógeno (JU et al, 2004). O teste in vivo, realizado em camundongos nude ovariectomizados mostra diminuição do crescimento tumoral 
nos animais tratados, refletindo a ação antiestrogênica do sitosterol, pois ele foi capaz de reduzir os níveis hormonais de estrogênio.

A interpretação de resultados obtidos com o tratamento por extratos de plantas em modelos in vivo ou in vitro se torna mais difícil pela complexidade existente na composição dos extratos. Além dos constituintes que podem possuir ações antagônicas, a quantidade existente no extrato é um fator importante.

De acordo com este estudo, a Pfaffia paniculata sugere possuir componentes interessantes para a pesquisa de antineoplásicos. O fracionamento do extrato butanólico pode revelar substâncias mais purificadas e com maior potencial contra células neoplásicas, que podem ser avaliados em testes subseqüentes em modelos in vitro e in vivo. 


\section{CONCLUSÕES}

- O tratamento com os extratos de Pfaffia paniculata produzem efeitos diferenciados, de acordo com o extrato estudado nas células MCF-7 e SKBR3, mostrando efeitos citotóxicos, nulos, ou estimulatórios.

- O extrato butanólico mostrou ser citotóxico nas linhagens MCF-7 e SKBR-3, enquanto o extrato aquoso demonstrou possuir efeito estimulatório sobre o crescimento de células MCF-7. O extrato etanólico não demonstrou efeitos significativos sobre o crescimento das células MCF-7 e SKBR-3.

- Ocorre morte celular na primeira hora de tratamento das células MCF-7 com o extrato butanólico. A morte celular continua a ocorrer nos tempos posteriores, mostrando alterações morfológicas das células tratadas.

- Não ocorre inibição de proliferação. As células MCF-7 tratadas com o extrato butanólico continuam a entrar em ciclo celular (fase $\mathrm{S}$ do ciclo celular).

- As células MCF-7 tratadas com $500 \mu \mathrm{g} / \mathrm{mL}$ e $1000 \mu \mathrm{g} / \mathrm{mL}$ do extrato butanólico apresentam alterações subcelulares profundas, indicativos de inviabilidade celular. 


\section{CONCLUSÃO FINAL}

A Pfaffia paniculata possui componentes tanto citotóxicos quanto estimulatórios sobre o crescimento e viabilidade de células tumorais mamárias humanas, presentes em diferentes extratos e responsáveis pelos efeitos observados. 


\section{REFERÊNCIAS}

ARLETTI, R.; BENELLI, A.; CAVAZZUTI, E.; SCARPETTA, G.; BERTOLINI, A. Stimulating property of Turnera diffusa and Pfaffia paniculata extracts on the sexual behavior of male rats. Psychopharmacology, v. 143, p. 15-19,1999.

ATTELE, A. S.; WU, J. A.; YUAN, C. S. Ginseng pharmacology. Multiple constituents and multiple actions. Biochemical Pharmacology, v. 58, p. 1685-93, 1999.

AWAD, A. B.; ROY, R.; FINK, C. S. $\beta$ - Sitosterol, a plant sterol, induces apoptosis and activates key caspases in MDA-MB-231 human breast cancer cells. Oncology Reports, v. 10, p. 497-500, 2003.

BALLAS, S. K. Hydratation of sickle erythrocytes using a herbal extract (Pfaffia paniculata) in vitro. British Journal of Haematology, v. 111, p. 359-362, 2000.

BRISKIN, D. P. Medicinal plants and phytomedicines. Linking plant biochemistry and physiology to human health. Plant Physiology, v. 124, p. 507-514, 2000.

BRITISH COLUMBIA MINISTRY OF AGRICULTURE AND FOOD. An information guide. GINSENG - what it is and isn't! parte 1, set. 1999. Disponível em: <http://www.agf.gov.bc.ca/speccrop/publications/documents/ginseng-what.pdf>. Acesso em: abr. 2005.

BUROW, M. E.; WELDON, C. B.; TANG, Y.; NAVAR, G. L.; KRAJEWSKI, S.; REED, J. C.; HAMMOND, T. G.; CLEJAN, S.; BECKMAN, S. Differences in susceptibility to Tumor Necrosis Factor $\alpha$-induced apoptosis among MCF-7 breast cancer cell variants. Cancer Research, v. 58, p. 4940-4946, 1998.

CASTEDO, M.; PERFETTINI, J. L.; ROUMIER, T.; ANDREAU, K.; MEDEMA, R.; KROEMER, G. Cell death by mitotic catastrophe: a molecular definition. Oncogene, v. 23, p. 2825-2837, 2004a.

CASTEDO, M.; PERFETTINI, J. L.; ROUMIER, T.; VALENT, A.; RASLOVA, H.; YAKUSHIJIN, K.; HORNE, D.; FEUNTEUN, J.; LENOIR, G.; MEDEMA, R.; VAINCHENKER, W.; KROEMER, G. Mitotic catastrophe constitutes a special case of apoptosis whose suppression entails aneuploidy. Oncogene, v. 23, p. 4362-4370, 2004b. 
CHANG, Y. S.; SEO, E. K.; GYLLRNHAAL, C.; BLOCK, K. I. Panax ginseng: a role in cancer therapy? Integrative Cancer Therapies, v. 2, n. 1, p. 13-33, 2003.

CHOI, Y. H.; KONG, K. R.; KIM, Y. A.; JUNG, K. O.; KIL, J. H.; RHEE, S. H.; Park, K. $\mathrm{Y}$. Induction of Bax and activation of caspases during beta-sitosterol-mediated apoptosis in human colon cancer cells. International Journal of Oncology, v. 23, n. 6, p. 1657-1662, 2003.

DWECK, A. C. Article on the South American Rainforest. Disponível em: <http://www.dweckdata.com/Published papers/Rainforest Plants.pdf >. Acesso em: 08 jun. 2005.

ELKINS, R. Medicinal herbs of the rain forest: uncovering the rain forest's natural medicines. Pleasant Grove (UT): Woodland Publishing, 1997. 154 p.

FORMIGLI, L.; PAPUCCI, L.; TANI, A.; SCHIAVONE, N.; TEMPESTINI, A.; ORLANDINI, G. E.; CAPACCIOLI, S.; ZECCHI ORLANDINI, S. Aponecrosis: morphological and biochemical exploration of a syncretic process of cell death sharing apoptosis and necrosis. Journal of Cellular Physiology, v. 182, p. 41-49, 2000.

FRANCIS, G.; KEREM, Z.; MAKKAR, H. P. S.; BECKER, K. The biological action of saponins in animal systems: a review. British Journal of Nutrition, v. 88, p. 587605, 2002.

GOOCH, J. L.; YEE, D. Strain-specific differences in formation of apoptotic DNA ladders in MCF-7 breast cancer cells. Cancer Letters, v. 144, p. 31-37, 1999.

HOSPITAL DO CÂNCER - A. C. CAMARGO. Departamento de Mastologia. São Paulo, 2005. Disponível em: <http://www.hcanc.org.br/dmeds/masto/mast1.html>. Acesso em jun. 2005.

INCA - INSTITUTO NACIONAL DE CÂNCER. MINISTÉRIO DA SAÚDE. Câncer de mama. Rio de Janeiro, 2005. Disponível em:

<http://www.inca.gov.br/conteudo_view.asp?id=336>. Acesso em jun. 2005.

INCA - INSTITUTO NACIONAL DE CÂNCER. MINISTÉRIO DA SAÚDE. Câncer no Brasil - dados dos registros de base populacional. Rio de Janeiro, 2003. Disponível em: <http://www.inca.gov.br/regpop/2003> Acesso em jun. 2005. 
INCA - INSTITUTO NACIONAL DE CÂNCER. MINISTÉRIO DA SAÚDE. Controle do câncer de mama - Documento de consenso. Rio de Janeiro, 2004. Disponível em: < http://www.inca.gov.br/publicacoes/Consensointegra.pdf > Acesso em jun. 2005.

JU, Y. H.; CLAUSEN, L. M.; ALLRED, K. F.; ALMADA, A. L.; HELFERICH, W. G. $\beta-$ sitosterol, $\beta$-sitosterol glucoside, and a mixture of $\beta$-sitosterol and $\beta$-sitosterol glucoside modulate the growth of estrogen-responsive breast cancer cells in vitro and in ovariectomized athymic mice. Journal of Nutrition, v. 134, p. 1145-1151, 2004.

LEVENSON, A. S.; JORDAN, V. C. MCF-7: the first hormone-responsive breast cancer cell line. Cancer Research, v. 57, p. 3071-3078, 1997.

MANS, D. R. A.; ROCHA, A. B.; SCHWARTSMANN, G. Anti-cancer drug discovery and development in Brazil: targeted plant collection as a rational strategy to acquire candidate anti-cancer compounds. The Oncologist, v. 5, p. 185-198, 2000.

MATSUZAKI, P.;AKISUE, G.; OLORIS, S. C. S.; GÓRNIAK, S. L.; DAGLI, M. L. Z. Effect of Pfaffia paniculata (Brazilian ginseng) on the Ehrlich tumor in its ascitic form. Life Sciences, v. 74, p. 573-579, 2003.

MAZZANTI, G.;BRAGHIROLI, L.; TITA, B.; BOLLE, P.; PICCINELLI, D. Antiinflammatory activity of Pfaffia paniculata (Martius) Kuntze and Pfaffia stenophhylla (Sprengel) Stuchl. Pharmacological Research, v. 27, n. 1, p. 91-92, 1993. Suplemento

MUIR, D.; VARON, S.; MANTHORPE, M. An ezyme-linked immunosorbent assay for bromodeoxyuridine incorporation using fixed microcutures. Analytical Biochemistry, v.185, p. 377-382, 1990.

NAKAI, S.; TAKAGI, N.; MIICHI, H.; HAYASHI, S.; NISHIMOTO, N.; TAKEMOTO, T.; $\mathrm{KIZU}, \mathrm{H}$. Pfaffosides, nortriterpenoid, saponins, from Pfaffia paniculata.

Phytochemistry, v. 23, n. 8, p. 1703-1705, 1984.

$\mathrm{NCI}$ - NATIONAL CANCER INSTITUTE. Drug Discovery at the National

Cancer Institute: Questions and Answers. Disponível em:

$<$ http://www.cancer.gov/newscenter/discovery>. Acesso em 2003. 
NISHIMOTO, N.; NAKAI, S.; TAKAGI, N.; HAYASHI, S.; TAKEMOTO, T.; ODASHIMA, S.; KIZU, H.; WADA, Y. Pfaffosides and nortriterpenoid saponins from Pfaffia paniculata. Phytochemistry, v. 23, n. 1, p. 139-142, 1984

OGA, S.; AKISUE, G.; FUJII, E.; STEPHAN, M.; TANIGUCHI, S. F. Triagem farmacológica de Pfaffia paniculata e Pfaffia stenophilla. Anais de Farmácia e Química de São Paulo, p. 40, 1987. Número especial

OLIVEIRA, F.; AKISUE, G.; AKISUE, M. K. Contribuição para o estudo farmacognóstico do "Ginseng Brasileiro" Pfaffia paniculata (Martius) Kuntze. Anais de Farmácia e Química de São Paulo, v. 20, n. 1/2, p. 261-277, 1980.

OSHIMA, M.; YEUNHWA, G. U. Pfaffia paniculata-induced changes in plasma estradiol-17 $\beta$, progesterone and testosterone levels in mice. Journal of Reproduction and Development, v. 49, n. 2, 2003.

PARADISE. Disponível em:

<http://www.paradiseherbs.com/images/PDF/GinsengBrazilian.pdf>. Acesso em: abr. 2005.

PEZZUTO, J. M. Plant-derived anticancer agents. Biochemical Pharmacology, v. 53, p. 121-133, 1997.

RØNNOV-JESSEN, L.; PETERSEN, O. W.; BISSEL, M. J. Cellular changes involved in conversion of normal to malignant breast: importance of the stromal reaction.

Physiological Reviews, v. 76, n. 1, p. 69-125, 1996.

SCHENKEL, E. P.; GOSMANN, G.; ATHAYDE M. L. Saponinas. In: SIMÕES, C M. O.; SCHENKEL, E. P.; GOSMANN, G.; MELLO, J. C. P.; MENTZ, L. A.; PETROVICK, P. R. Farmacognosia da planta ao medicamento. 4. ed. Florianópolis: Ed. da UFSC, 2002, p. 607-632.

SCHILSKY, R. L.; MILANO, G. A.; RATAIN, M. J. Principles of antineoplastic drug development and pharmacology. New York: Marcel Dekker, 1996. 741 p.

SHIBATA, S. Chemistry and cancer preventing activities of ginseng saponins and some related triterpenoid compounds. Journal of Korean Medical Science, v. 16, p. S28-37, 2001. Suplemento. 
SILVA, T. C. da. Efeitos da Pfaffia paniculata (ginseng brasileiro) sobre lesões pré-neoplásicas em camundongos submetidos a modelo de hepatocarcinogênese. 2003. 140 f. Dissertação (Mestrado em Ciências) Faculdade de Medicina Veterinária e Zootecnia, Universidade de São Paulo, São Paulo, 2003.

SOCIEDADE BRASILEIRA DE MASTOLOGIA. Recomendações do consenso. Projeto Diretrizes: Diagnóstico e tratamento do câncer de mama. Rio de Janeiro, 2001. Disponível em:

<http://www.sbmastologia.com.br/site/conheca/projeto_diretriz/projeto_diretriz.asp> Acessado em: jun. 2005.

SOULE, H. D.; VAZQUEZ, J.; LONG, A.; ALBERT, S.; BRENNAM, M. A human cell line from a pleural effusion derived from a breast carcinoma. Journal of the National Cancer Institute. v. 51, n. 5, p. 1409-1416.

SPECTOR, D. L.; GOLDMAN, R.D.; LEINWAND, L. A. Apoptosis assays. In: Cells: a laboratory manual. Cold Spring Harbor, NY: Cold Spring Harbor Laboratory Press, 1998, v. 1, p. 15.6.

TAKEMOTO, T.; NISHIMOTO, N.; NAKAI, S.; TAKAGI, N.; HAYASHI, S.; ODASHIMA, S.; WADA, Y. Pfaffic acid, a novel nortriterpene from Pfaffia paniculata Kuntze. Tetrahedron Letters, v. 24, n. 10, p. 1057-1060, 1983.

TEICHER, B. A. Anticancer drug development guide: preclinical screening, clinical trials, and approval. Totowa, New Jersey: Humana Press, 1997. 311 p.

WATANABE, T.; WATANABE, M.; WATANABE, Y.; HOTTA, C. Effects of oral administration of Pfaffia paniculata (Brazilian ginseng) on incidence of spontaneous leukemia in AKR/J mice. Cancer Detection and Prevention, v. 24, n. 2, p. 173-178, 2000.

ZAJCHOWSKI, D. A.; BARTHOLDI, M. F.; GONG, Y.; WEBSTER, L.; LIU, H. L.; MUNISHKIN, A.; BEAUHEIM, C.; HARVEY, S.; ETHIER, S. P.; JOHNSON, P. H. Identification of gene expression profiles that predict the aggressive behavior of breast cancer cells. Cancer Research, v. 61, p. 5168-5178, 2001.

ZIEGLER, U.; GROSCURTH, P. Morphological features of cell death. News in Physiological Sciences, v. 19, p.124-128, 2004. 